\title{
Assessing the role of industry 4.0 for enhancing swift trust and coordination in humanitarian supply chain
}

\author{
Masoud Shayganmehr ${ }^{1}$. Shivam Gupta ${ }^{1}$ (D) - Issam Laguir ${ }^{2} \cdot$ Rebecca Stekelorum $^{3}$. \\ Ajay Kumar ${ }^{4}$
}

Accepted: 10 November 2021

(c) The Author(s), under exclusive licence to Springer Science+Business Media, LLC, part of Springer Nature 2021

\begin{abstract}
Unpredictable natural and man-made disasters highlight importance of humanitarian supply chain (HSC) to serve people and affected areas. The main challenges of applying effective relief operations are creating "swift trust" and "coordination" between aid organizations. Implementation of Industry 4.0 facilitates coordination and swift trust within HSC performance. The study intends to assess the readiness status of swift trust and coordination between stakeholders as well as to recommend the most suitable Industry 4.0 tools for improving relief operations. Firstly, a comprehensive set of critical success factors for implementing Industry 4.0 tools are introduced. The factors are categorized into limited groups using Exploratory Factor Analysis. In the next step, hierarchy fuzzy expert system is designed for assessing the readiness status of swift trust and coordination as well as to suggest the most suitable Industry 4.0 tool for enhancing HSC performance within given case study. The framework was applied for three aid organizations to address the pandemic disease in Iran. The outcome denotes that the organization has the highest readiness in logistic and transparency while information quality received the lowest readiness value. In addition to that, the organization
\end{abstract}

Shivam Gupta

shivam.gupta@neoma-bs.fr

Masoud Shayganmehr

masoud.shayganmehr@neoma-bs.com

Issam Laguir

i.laguir@montpellier-bs.com

Rebecca Stekelorum

rebecca.stekelorum@icn-artem.com

Ajay Kumar

akumar@em-lyon.com

1 Department of Information Systems, Supply Chain Management and Decision Support, NEOMA Business School, 59 Rue Pierre Taittinger, 51100 Reims, France

2 Montpellier Business School, 2300 Avenue des Moulins, 34185 Montpellier, France

3 Department of Strategy and Entrepreneurship, ICN Business School, CEREFIGE, 54000 Nancy, France

4 AIM Research Centre on Artificial Intelligence in Value Creation, EMLYON Business School, 23 Avenue Guy de Collongue, 69130 Ecully, France 
should invest on the development of Industry 4.0 enablers including "Internet of Things and Big Data Analytics". The study extends organizational information process theory within HSC for reaching competitive advantage by information processing. The study suggests theoretical and practical implications by introducing a comprehensive set of critical success factors for implementation of Industry 4.0 and providing practical advice for enhancing HSC performance.

Keywords Humanitarian supply chain · Empirical study · Organizational information processing theory $\cdot$ Relief operations

\section{Introduction}

Over the past few years, Humanitarian Supply Chain (HSC) has attracted the researchers' attentions to explore the theme more deeply due to frequent occurrence of unpredictable disasters such as pandemic disease (like COVID-19), earthquake, flood and man-made disaster like terrorist attacks (Dubey et al., 2021; Kumar \& Singh, 2021). A disaster has widespread effects on different aspects of society and government sectors. A disaster not only affects the human being and take people's lives but also it hampers the development of tourism and economy and it has long-lasting environmental, economic and social consequence on the society (Fosso Wamba, 2020; Kumar \& Singh, 2021).

Since HSC is conducted between different aid organizations at the outbreak of disasters, they are required to provide relief operations to serve the most affected areas and people. However, the complexity of coordination between high number of aid organizations and personals makes the relief operations so sophisticated and inefficient (de Camargo Fiorini et al., 2021).

HSC calls for high level of collaboration and coordination between actors including government, military agencies, civil society and private entities to serve the most effected people. This network is considered as HSC which is responsible for providing assistance in terms of medical supports, food and all required supporting services for the affected area (de Camargo Fiorini et al., 2021). HSC is defined as the mobility of recourses and people aiming at saving people's lives and helping affected areas. The main objective of HSC is saving people lives and mitigating the affected society suffering during disaster time (Kumar \& Singh, 2021).

HSC is not limited to restricted activities between aid organizations. There are plenty of activities which should be considered during and after the outbreak of disaster including needs assessment, planning, procurement and warehousing (Kumar \& Singh, 2021; Modgil et al., 2020).

The random outbreak of disasters calls for immediate actions from responsible organizations to deal with the situation and meet affected people's requirements (Xu et al., 2021). The main and preliminary action is creating "coordination" between organizations to serve the needed people with the most efficient relief operations. One of the main aspects of coordination is information sharing between actors and try to equip them with transparency and precise information regarding the magnitude of disaster (Dubey et al., 2021; Kumar \& Singh, 2021). Such information can extend decision makers vision to better understand the affected areas and people and make more logical and practical decisions (Kumar \& Singh, 2021).

Coordination between stakeholders within HSC can take place in different ways such as quality information flow, visibility of items movement and distribution in the affected areas. Coordination is so essential in HSC because it helps aid organizations to conduct better 
evaluation of affected area and people to make an efficient relief operation (John et al., 2020; Kumar \& Singh, 2021). Moreover, efficient coordination decreases the operation costs and accelerates the response time (Fuli et al., 2020; Kumar \& Singh, 2021).

Coordination between responsible organizations is the main challenging factor in postdisaster functions for HSC. Due to unpredictability of natural and man-made disaster, it has become so complicated to provide coordination within aid organizations to provide high quality services to the affected people and area (Koliousis et al., 2020).

HSC is suffering from real-time information, coordination and information sharing and communication between aid organizations which causes to poor fulfillment of affected people's requirements and inability to provide assistance to last mile area (Nagendra et al., 2020; Prasanna \& Haavisto, 2018). Absence of coordination between actors increases the complexity of delivering relief operations. Moreover, disseminating misinformation stemming from social media hampers rescue operations. Deploying the most effective relief operations within HSC completely relies on the information quality of affected area and people (Prasanna \& Haavisto, 2018). Decision making for providing more efficient relief operations can be enhanced by applications of Information and Communication Technology (ICT) (Nagendra et al., 2020).

With the outbreak of disaster, all aid organizations are supposed to have cooperation and collaborations to form HSC as soon as possible. Another main and preliminary requirement of providing efficient relief operations is creating swift trust within aid organizations and stakeholders to serve the affected people and areas (Behl et al., 2020; Dubey et al., 2020).

Lack of trust and transparency causes to poor collaboration between actors in HSC (Dubey et al., 2020). Lack of trust is a major issue for cooperation in HSC. Cooperation requires information sharing between actors during the outbreak of disaster. In order to provide more collaboration and transparency between actors within HSC, there should be swift trust between stakeholders which can take place through information sharing (Dubey et al., 2020; Modgil et al., 2020). Swift trust is one of the main pillars of coordination within HSC. Moreover, both swift trust and coordination have progressive effect on supply chain resilience. (Dubey et al., 2020; Modgil et al., 2020).

One of the best and effective ways to enhance coordination and swift trust between aid organizations is applying Industry 4.0 during the outbreak of disaster (Kumar \& Singh, 2021; Marić et al., 2021). The previous studies have already mentioned and highlighted the important role of Industry 4.0 for improving coordination between actors within commercial supply chain but the role of Industry 4.0 for HSC is scarce and not well-explored (Ho et al., 2021; Singh et al., 2018). A few studies have highlighted the critical role of industry 4.0 in providing better coordination and swift trust between stakeholders (Bag et al. 2020a; b). Prior to implementation of Industry 4.0 for improving swift trust and coordination, there is a dire need to evaluate the readiness status of coordination and swift trust based on the most valid "Critical Success Factors". Such assessment makes a strong contribution to better understanding of the entire HSC and spot the weakness and strength of efficiency of HSC during the disaster period (Shafiq \& Soranata, 2020).

From the Organizational Information Process (OIP) theory perspective, better analysis of information flow between different aid organizations helps mitigate the uncertainty within operations and enables them to make more logical decision based on credible data processing. Such issue makes a contribution to aid organizations to gain competitive advantages through meticulous analysis of data flow between organizations.

There is high concentration on increasing preparedness how to manage disaster prior to its outbreak with high emphasis on application of Industry 4.0 to support efficient decision making. Nagendra et al. (2020) concentrated on catalyzing and facilitating the coordination 
between actors through Big Data Analytics. It is seen as one of the main aspects of agile supply chain to provide assistance to affected population. Bag et al. (2020a; b) believe that Big Data Analytics can bring higher visibility to supply chain actors by accessing to real-time information. Accurate information can accelerate relief operations as well as to coordinate between aid organizations. Dubey et al. (2020) proved that Blockchain makes a contribution to increasing transparency and better data sharing between HSC actors. As a result, it intends to increase the trust between stakeholders. As it is explained, each Industry 4.0 tool including "Big Data Analytics", "Internet of Things (IoT)", "Cyber physical system", "Cloud computing" and "Blockchain" provides specific benefits which are different from others (Bag et al., 2020a; b; Dubey et al., 2020). Industry 4.0 tools are context-based and according to the considered case study, one of the industry 4.0 tools is going to be considered as the most effective one for improving coordination and swift trust. Moreover, having all of them during the relief operations within HSC is so expensive and impossible to be implemented (Dubey et al., 2020). Therefore, there is a dire need to prioritize the industry 4.0 tools and propose one of them to be considered for the given case study for improving coordination and swift trust.

Following the above explanations the main research questions are formulated as:

RQ1. How to develop a framework for assessing the readiness status of the two main aspects of HSC performance including "Swift trust" and "Coordination" as well as to provide some practical advice for their improvement within the given case study?

RQ2. What are the critical success factors for implementing Industry 4.0 tools aiming at improving swift trust and coordination?

RQ3. How to develop a framework to suggest the most appropriate Industry 4.0 tool for the given case study aiming at enhancing "Swift trust" and " Coordination" within HSC?

The study makes contribution to enhancing swift trust and coordination within HSC performance with the aid of Industry 4.0 tools. The most important ones are:

- Introducing a comprehensive set of critical success factors for improving Industry 4.0 within HSC network as well as categorizing the most relevant factors into limited constructs.

- Assessing the readiness status of swift trust and coordination as well as to recommend some practical advice for improving efficiency of HSC performance.

- Extending OIP theory for getting competitive advantages through analyzing the affected people and areas' information within HSC network.

- Proposing the most needed Industry 4.0 tool for considered case study including "Big Data Analytics", "IoT", "Blockchain", "Cloud computing" and "Cyber physical system" for improving HSC resilience during the disaster period.

The next section is allocated for literature review to introduce the fundamental research concepts and the most relevant studies. Section 3 is allocated for introducing the hybrid research methodology including Exploratory Factor Analysis (EFA) and Hierarchy fuzzy expert system. In Sect. 4, the suggested framework is applied for the case study and readiness status of constructs are evaluated. The next section is allocated for discussion of final outcome as well as to highlight the research implications. 


\section{Literature review}

\subsection{Organizational information process theory}

OIP theory was firstly proposed by Thompson (1697) and was further developed by Tushman and Nadler (1987). The theory mostly concentrates on the flow of information within and around organization and how processing such information can help organizations reach competitive advantages and improve the organization performance (Dubey et al., 2019).

Information processing makes a strong contribution to mitigating the uncertainty between required information to conduct a task and the level of available information within the organization (Dubey et al., 2019).

In addition to that, better information processing enables decision makers to make more efficient decision and equip them with rich insights to make more effective and stronger plan with minimum cost and side effect as well as enhancing organization's performance (Dubey et al., 2019).

\subsection{Coordination within HSC}

Engagement of different and dozens of aid organizations within HSC makes the network so complicated and difficult to have collaboration between each other. Coordination between stakeholders is the most complicated task within HSC to serve the affected population during the disaster period (Kumar \& Singh, 2021). The success of relief operations totally depends on accurate and meticulous coordination between aid organizations to provide the optimized medical and supporting services to the affected areas. Otherwise, poor coordination can cause loss of many people's lives, inefficient use of resources and rise of support cost. In spite of various researches for improving coordination between aid organizations, it is still seen as the main challenging issue and main weakness of providing efficient HSC (Dubey et al., 2018).

In fact, coordination is responsible for striking a balance between demand and supply which leads to efficient use of resources and avoiding duplication of relief operations during the disaster time. The sudden congregation of aid organizations to conduct relief operations within the limited time period makes the operation so complicated and difficult (Dubey et al., 2018; Kumar \& Singh, 2021).

Based on the above explanation, there is an urgent need to reconsider coordination between stakeholders more deeply and try to propose a new solution for overcoming such prolonging existing challenge.

\subsection{Swift trust within HSC}

It is highlighted by scholars that lack of trust between actors is the main challenging issue in supply chain because lack of trust between suppliers prevents them from having cooperation between each other and finally it leads to decreasing HSC performance. Since time and immediate actions are highly required at the outbreak of disasters, therefore, building swift trust between HSC stakeholders are so crucial and necessary to serve people efficiently (Dubey et al., 2019).

Transparency and sharing information are the best ways to increase swift trust between HSC actors. It is highly highlighted that those companies which have highest level of information exchange between HSC actors leads to building trust and commitment between actors during the relief operations (Dubey et al., 2018). 
Following the above explanation, the second most important factors for increasing HSC efficiency is creating swift trust which has direct impact on increasing collaboration and cooperation between HSC actors. Moreover, swift trust can be increased mostly by creating higher transparency and information exchange between HSC actors (Dubey et al., 2018, 2019).

\subsection{Application of industry 4.0 within HSC and research gaps}

Numerous studies have been published so far to highlight the critical role of swift trust and coordination for commercial and HSC actors. Despite high numbers of academic research to improve these two factors within HSC, it is still a challenging issue for researchers and is considered as trending theme between academicians (Kumar \& Singh, 2021).

Information Technologies (IT) plays a crucial role in coordination, flexibility and competitiveness of suppliers in supply chain (Bag et al., 2020a; b; Nunes \& Pereira, 2021). Moreover, Industry 4.0 can be considered as the mediator factor for increasing swift trust and coordination between HSC stakeholders. Emerging technologies such as Big Data Analytics and Blockchain facilitate coordination and swift trust between all HSC stakeholders and have direct impact on efficiency of HSC performance (Dubey et al., 2020; Sahebi et al., 2020). Therefore, a systematic literature review is conducted to recognize the most relevant studies.

A systematic literature review is pursued to select one of the most credible and available online databases. The most popular databases are Scopus, Web of Science, and Science Direct. The SCOPUS is selected for the study. The main reasons are high precision citations and containing more than 2000 periodicals comparing to Science Direct and Web of Science (Jabbour et al., 2019). The systematic literature review is conducted based on following keywords presented in Table 1.

The initial search results presented 33 papers including scientific articles, review papers, conference papers, and book chapters. In order to select high quality papers for the research, journals papers were selected to conduct for further analysis and conference papers and book chapters were omitted from the list. Moreover, the selected journal papers come under meticulous review to check whether they are relevant to the scope of the research. Finally, 13 credible journal papers were selected to be considered for the current research. The selected papers' publication period was between 2016 and 2021. Figure 1 shows the sequence of systematic literature review and Table 2 denotes the most relevant selected papers.

Table 1 Keywords searching

\begin{tabular}{|c|c|}
\hline Keywords & Quantity \\
\hline "Humanitarian Supply chain" OR "Relief Operations" AND "Industry 4.0" & 2 Papers \\
\hline "Humanitarian Supply chain" OR "Relief Operations" AND "Internet of things" OR "IoT" & 8 Papers \\
\hline "Humanitarian Supply chain” OR "Relief Operations" AND "Cyber physical system" & 1 Paper \\
\hline "Humanitarian Supply chain” OR "Relief Operations" AND “Cloud computing” & 7 Papers \\
\hline "Humanitarian Supply chain" OR "Relief Operations" AND "Big data" & 7 Papers \\
\hline "Humanitarian Supply chain" OR "Relief Operations" AND "Blockchain" & 1 Paper \\
\hline "Humanitarian Supply chain" OR "Relief Operations" AND "Industry 4.0" & 7 Papers \\
\hline Total & 33 Papers \\
\hline
\end{tabular}




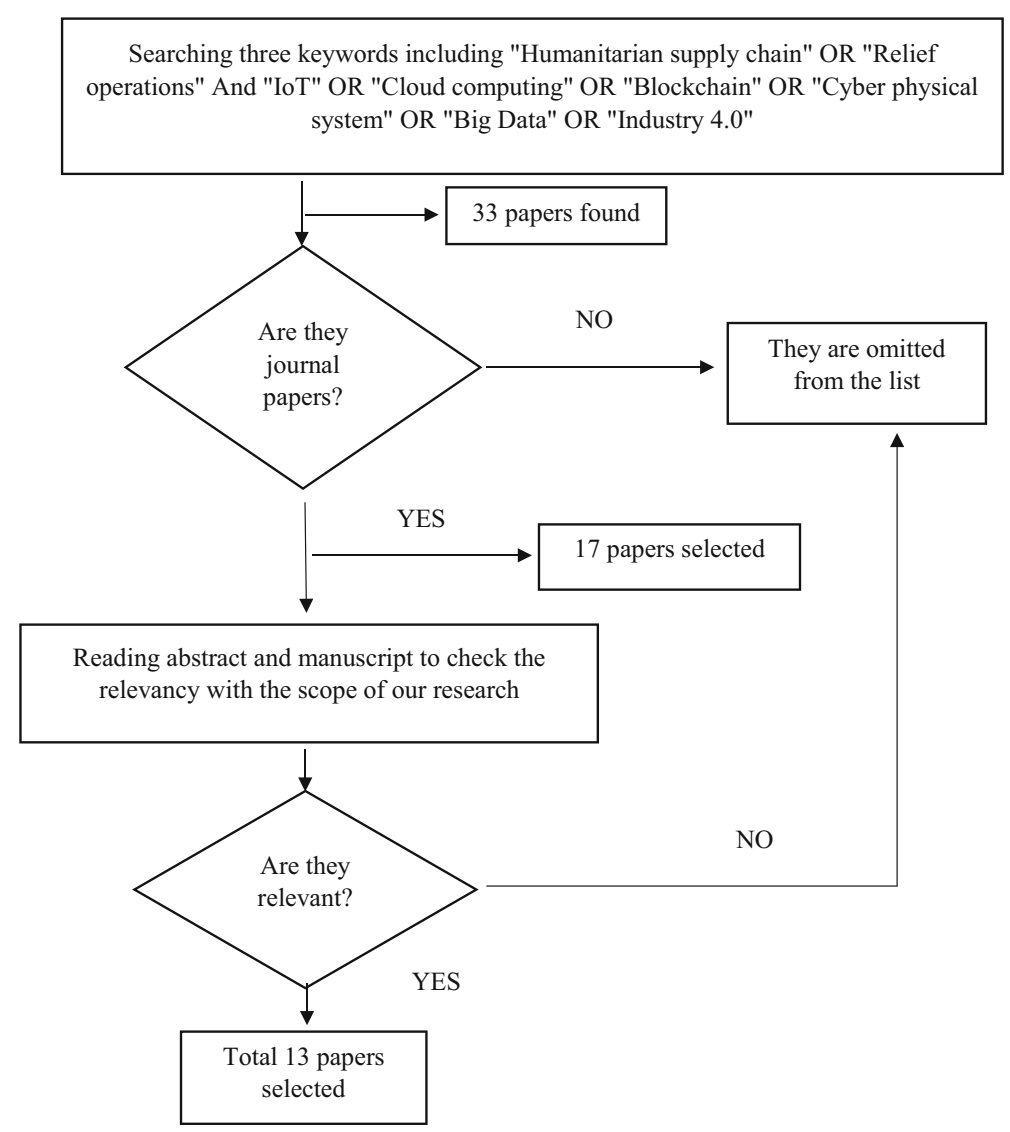

Fig. 1 The sequence of systematic literature review

As it is shown in the Table 2, there are few studies exploring the significant role of Industry 4.0 for improving HSC performance during disaster period such as facilitating the coordination and information flow within complicated HSC actors. The studies assessed one of the main Industry 4.0 pillars including "Big Data Analytics", "IoT", "Cyber physical system", "Cloud computing", and "Blockchain". Nagendra et al. (2020) have proposed a framework for assessing the role of satellite big data analytics for improving real-time data transaction and data accuracy at the outbreak of disaster while telecommunication infrastructure is leveled down. Sinha et al. (2019) have evaluated the effect of IoT on meeting requirements of HSC during the disaster time by providing real-time and reliable information to the aid organizations. Jeble et al. (2019) determined the important role of big data analytics and social capital on the improvement of HSC. Dubey et al. (2019) explored the significant role of big data analytics in increasing swift trust and collaboration within HSC.

Based on the previous studies, each Industry 4.0 tool (including "Big Data Analytics", "IoT", "Cyber physical system", "Cloud computing" and "Blockchain") has specific benefits for improvement of HSC such as swift trust and coordination between stakeholders. For instance, Big Data Analytics makes a contribution to better analysis of collected data from various resources for making better decision (Bag et al. 2020a; b). IoT provides real-time 
Table 2 The most relevant studies

\begin{tabular}{|c|c|c|c|c|c|}
\hline Reference & Description & $\begin{array}{l}\text { Research } \\
\text { methodology }\end{array}$ & $\begin{array}{l}\text { Industry } 4.0 \\
\text { pillars }\end{array}$ & Applied theory & Indicator \\
\hline $\begin{array}{l}\text { Kumar and Singh } \\
\text { (2021) }\end{array}$ & $\begin{array}{l}\text { The study } \\
\text { investigated } \\
\text { the } \\
\text { important } \\
\text { role of } \\
\text { Industry } 4.0 \\
\text { for } \\
\text { improving } \\
\text { coordina- } \\
\text { tion within } \\
\text { HSC by } \\
\text { assigning } \\
\text { weight and } \\
\text { ranking } \\
\text { indicators }\end{array}$ & $\begin{array}{l}\text { Hybrid } \\
\text { multi-criteria } \\
\text { decision- } \\
\text { making } \\
\text { methods }\end{array}$ & $\begin{array}{l}\text { Big data } \\
\text { IoT } \\
\text { Cyber } \\
\text { physical- } \\
\text { security } \\
\text { Cloud } \\
\text { computing }\end{array}$ & $\begin{array}{l}\text { System theory } \\
\text { and resource- } \\
\text { based } \\
\text { view }\end{array}$ & $\begin{array}{l}\text { System } \\
\text { architecture } \\
\text { Cross } \\
\text { functional } \\
\text { teams } \\
\text { System } \\
\text { integration } \\
\text { Resource } \\
\text { management } \\
\text { Financial } \\
\text { supply chain } \\
\text { Strategic } \\
\text { planning } \\
\text { Mechanism } \\
\text { for } \\
\text { coordination } \\
\text { Data } \\
\text { processing } \\
\text { and sharing } \\
\text { Training } \\
\text { Local } \\
\text { communities } \\
\text { Real-time data } \\
\text { Traceability } \\
\text { Swift trust } \\
\text { Needs } \\
\text { assessment } \\
\text { Logistic } \\
\text { automation }\end{array}$ \\
\hline $\begin{array}{l}\text { Sharma and Joshi } \\
\text { (2020) }\end{array}$ & $\begin{array}{l}\text { The study has } \\
\text { investigated } \\
\text { the potential } \\
\text { risk of } \\
\text { application } \\
\text { of big data } \\
\text { analytics } \\
\text { within HSC }\end{array}$ & $\begin{array}{c}\text { Systematic } \\
\text { literature } \\
\text { review }\end{array}$ & Big data analytics & None & None \\
\hline $\begin{array}{l}\text { Rodriguez-Espindola } \\
\text { et al. (2020) }\end{array}$ & $\begin{array}{l}\text { The research } \\
\text { proposed a } \\
\text { framework } \\
\text { for } \\
\text { facilitating } \\
\text { flow of } \\
\text { information } \\
\text { by } \\
\text { applications } \\
\text { of three } \\
\text { disruptive } \\
\text { technolo- } \\
\text { gies }\end{array}$ & $\begin{array}{c}\text { Case study } \\
\text { analysis }\end{array}$ & $\begin{array}{l}\text { Artificial } \\
\text { intelligence } \\
\text { 3D printing } \\
\text { Blockchain }\end{array}$ & None & $\begin{array}{l}\text { Information } \\
\text { accuracy } \\
\text { Procurement } \\
\text { process } \\
\text { Budget and } \\
\text { accountability }\end{array}$ \\
\hline
\end{tabular}


Table 2 (continued)

\begin{tabular}{|c|c|c|c|c|c|}
\hline Reference & Description & $\begin{array}{l}\text { Research } \\
\text { methodology }\end{array}$ & $\begin{array}{l}\text { Industry } 4.0 \\
\text { pillars }\end{array}$ & Applied theory & Indicator \\
\hline $\begin{array}{l}\text { Nagendra et al. } \\
\qquad(2020)\end{array}$ & $\begin{array}{l}\text { The research } \\
\text { explored } \\
\text { how } \\
\text { satellite big } \\
\text { data } \\
\text { analytics } \\
\text { improve the } \\
\text { real-time } \\
\text { data and } \\
\text { accuracy of } \\
\text { data in } \\
\text { relief } \\
\text { operations } \\
\text { during } \\
\text { disaster }\end{array}$ & $\begin{array}{c}\text { Case study } \\
\text { analysis }\end{array}$ & Big data analytics & None & None \\
\hline Dubey et al. (2020) & $\begin{array}{l}\text { The study } \\
\text { highlighted } \\
\text { the } \\
\text { significant } \\
\text { role of } \\
\text { blockchain } \\
\text { on } \\
\text { enhancing } \\
\text { swift trust } \\
\text { and further } \\
\text { collabora- } \\
\text { tion } \\
\text { between } \\
\text { supply } \\
\text { chain actors } \\
\text { in HSC for } \\
\text { reaching } \\
\text { higher } \\
\text { resilience } \\
\text { after the } \\
\text { outbreak of } \\
\text { disaster }\end{array}$ & $\begin{array}{c}\text { Hypothesis } \\
\text { testing }\end{array}$ & Blockchain & $\begin{array}{l}\text { OIP and } \\
\text { relational } \\
\text { view theory }\end{array}$ & $\begin{array}{l}\text { Transparency } \\
\text { Swift trust } \\
\text { Collaboration } \\
\text { Supply chain } \\
\text { resilience }\end{array}$ \\
\hline
\end{tabular}


Table 2 (continued)

\begin{tabular}{|c|c|c|c|c|c|}
\hline Reference & Description & $\begin{array}{l}\text { Research } \\
\text { methodology }\end{array}$ & $\begin{array}{l}\text { Industry } 4.0 \\
\text { pillars }\end{array}$ & Applied theory & Indicator \\
\hline $\begin{array}{l}\text { Bag et al., (2020a, } \\
\text { 2020b) }\end{array}$ & $\begin{array}{l}\text { The research } \\
\text { determined } \\
\text { the most } \\
\text { critical } \\
\text { barriers in } \\
\text { implement- } \\
\text { ing big data } \\
\text { analytics } \\
\text { system for } \\
\text { better coor- } \\
\text { dination } \\
\text { between } \\
\text { HSC actors. } \\
\text { The study } \\
\text { determined } \\
\text { the } \\
\text { association } \\
\text { between the } \\
\text { barriers }\end{array}$ & $\begin{array}{l}\text { Fuzzy total } \\
\text { interpretive } \\
\text { structural } \\
\text { modeling } \\
\text { (TISM) }\end{array}$ & Big data analytics & None & $\begin{array}{l}\text { Poor } \\
\text { management } \\
\text { Multiple } \\
\text { formats } \\
\text { Lack of skills } \\
\text { Training } \\
\text { Complexity } \\
\text { Fear of new } \\
\text { technology } \\
\text { Infrastructure } \\
\text { readiness } \\
\text { Employee's } \\
\text { mindsets } \\
\text { Organization } \\
\text { culture } \\
\text { New } \\
\text { employee } \\
\text { development } \\
\text { Modern } \\
\text { management } \\
\text { practices } \\
\text { Poor } \\
\text { infrastructure } \\
\text { Quality } \\
\text { information } \\
\text { Public and } \\
\text { private } \\
\text { partnership } \\
\text { Funding }\end{array}$ \\
\hline Sinha et al. (2019) & $\begin{array}{l}\text { The study } \\
\text { assessed the } \\
\text { critical role } \\
\text { of IoT in } \\
\text { meeting } \\
\text { HSC } \\
\text { requirement }\end{array}$ & $\begin{array}{l}\text { Hypothesis } \\
\text { testing }\end{array}$ & IoT & None & $\begin{array}{l}\text { Situational } \\
\text { awareness } \\
\text { Consistency } \\
\text { Reliability } \\
\text { Monitoring } \\
\text { Miscellaneous }\end{array}$ \\
\hline Jeble et al. (2019) & $\begin{array}{l}\text { The research } \\
\text { determined } \\
\text { the } \\
\text { important } \\
\text { role of big } \\
\text { data } \\
\text { analytics } \\
\text { and social } \\
\text { capital on } \\
\text { the } \\
\text { improve- } \\
\text { ment of } \\
\text { HSC }\end{array}$ & $\begin{array}{c}\text { Systematic } \\
\text { literature } \\
\text { review }\end{array}$ & Big data analytics & $\begin{array}{l}\text { Resource-based } \\
\text { view and } \\
\text { social capital } \\
\text { theories }\end{array}$ & $\begin{array}{l}\text { Basic resources } \\
\text { Data } \\
\text { Technology } \\
\text { Tech skills } \\
\text { Management } \\
\text { skills } \\
\text { Culture } \\
\text { Organizational } \\
\text { learning } \\
\text { Trust } \\
\text { Social norms } \\
\text { Participation } \\
\text { Network }\end{array}$ \\
\hline
\end{tabular}


Table 2 (continued)

\begin{tabular}{|c|c|c|c|c|c|}
\hline Reference & Description & $\begin{array}{l}\text { Research } \\
\text { methodology }\end{array}$ & $\begin{array}{l}\text { Industry } 4.0 \\
\text { pillars }\end{array}$ & Applied theory & Indicator \\
\hline Gupta et al. (2019) & $\begin{array}{l}\text { The research } \\
\text { conducted } \\
\text { extensive } \\
\text { literature } \\
\text { review to } \\
\text { identify } \\
\text { relevant } \\
\text { studies } \\
\text { exploring } \\
\text { the } \\
\text { significant } \\
\text { role of big } \\
\text { data on } \\
\text { HSC }\end{array}$ & $\begin{array}{c}\text { Systematic } \\
\text { literature } \\
\text { review }\end{array}$ & Big data analytics & $\begin{array}{l}\text { Organizational } \\
\text { theory }\end{array}$ & $\begin{array}{l}\text { Humanitarian } \\
\text { logistic } \\
\text { Remote } \\
\text { sensing } \\
\text { Information } \\
\text { security } \\
\text { Social media }\end{array}$ \\
\hline Dubey et al. (2019) & $\begin{array}{l}\text { The research } \\
\text { explored the } \\
\text { significant } \\
\text { role of big } \\
\text { data } \\
\text { analytics in } \\
\text { increasing } \\
\text { swift trust } \\
\text { and collabo- } \\
\text { ration } \\
\text { within HSC }\end{array}$ & $\begin{array}{l}\text { Hypothesis } \\
\text { testing }\end{array}$ & Big data analytics & OIP theory & $\begin{array}{l}\text { Flexible } \\
\text { orientation } \\
\text { Control } \\
\text { orientation } \\
\text { Swift trust } \\
\text { Collaborative } \\
\text { performance }\end{array}$ \\
\hline Prasad et al. (2018) & $\begin{array}{l}\text { The research } \\
\text { identified } \\
\text { how big } \\
\text { data can } \\
\text { exert more } \\
\text { power to } \\
\text { responsible } \\
\text { companies } \\
\text { to better } \\
\text { coordinate } \\
\text { relief } \\
\text { actions }\end{array}$ & $\begin{array}{l}\text { Case } \\
\text { methodology }\end{array}$ & Big data analytics & $\begin{array}{l}\text { Resource } \\
\text { dependence } \\
\text { theory }\end{array}$ & None \\
\hline Dubey et al. (2018) & $\begin{array}{l}\text { The study } \\
\text { highlighted } \\
\text { the } \\
\text { important } \\
\text { role of big } \\
\text { data } \\
\text { analytics in } \\
\text { improving } \\
\text { coordina- } \\
\text { tion under } \\
\text { shadow of } \\
\text { swift trust }\end{array}$ & $\begin{array}{l}\text { Hypothesis } \\
\text { testing }\end{array}$ & Big data analytics & $\begin{array}{l}\text { Contingent } \\
\text { resource- } \\
\text { based view } \\
\text { theory }\end{array}$ & $\begin{array}{l}\text { Basic resource } \\
\text { Data } \\
\text { Technology } \\
\text { Technical } \\
\text { skills } \\
\text { Management } \\
\text { skills } \\
\text { Organizational } \\
\text { skills } \\
\text { Organizational } \\
\text { learning }\end{array}$ \\
\hline
\end{tabular}


Table 2 (continued)

\begin{tabular}{|c|c|c|c|c|c|}
\hline Reference & Description & $\begin{array}{l}\text { Research } \\
\text { methodology }\end{array}$ & $\begin{array}{l}\text { Industry } 4.0 \\
\text { pillars }\end{array}$ & Applied theory & Indicator \\
\hline $\begin{array}{l}\text { Schniederjans et al. } \\
\text { (2016) }\end{array}$ & $\begin{array}{l}\text { The study } \\
\text { examined } \\
\text { the role of } \\
\text { cloud } \\
\text { computing } \\
\text { in } \\
\text { increasing } \\
\text { collabora- } \\
\text { tion and } \\
\text { HSC agility } \\
\text { between } \\
\text { suppliers }\end{array}$ & $\begin{array}{l}\text { Interview and } \\
\text { survey analysis }\end{array}$ & Cloud computing & $\begin{array}{l}\text { Social capital } \\
\text { theory } \\
\text { Technology } \\
\text { acceptance } \\
\text { model }\end{array}$ & $\begin{array}{l}\text { Collaboration } \\
\text { Inter } \\
\text { organizationa } \\
\text { trust } \\
\text { Agility }\end{array}$ \\
\hline
\end{tabular}

data collection and enable stakeholders to easily exchange information during the disaster time (Sinha et al., 2019). Blockchain enables data to be stored between distributed databases and causes higher transparency between stakeholders at the outbreak of disaster (RodriguezEspindola et al., 2020). Such benefits allow decision makers to make a better and accurate decision within the sensitive time.

Practically speaking, having all Industry 4.0 tools (including "Big Data Analytics", "IoT", "Cyber physical system", "Cloud computing" and "Blockchain") together for improving HSC performance is impossible due to high cost, time and energy consumption. Therefore, prioritizing the implementation of industry 4.0 tools according to the considered case study can cause huge benefits for aid organizations to serve the most efficient and optimized services to the affected population and areas as well as increasing swift trust and coordination between stakeholders strongly. The first research gap is:

Absence of a study to propose and prioritize the most efficient Industry 4.0 tool (including "Big Data Analytics", "IoT", "Cyber physical system", "Cloud computing" and "Blockchain") based on the given case study for improving coordination and swift trust between stakeholders.

The previous studies directly discuss the advantages and potential benefits of Industry 4.0 tools for improving HSC performance. Radriguez-Espindola et al. (2020) believe that three disruptive technologies including 3D printing, blockchain and artificial intelligence facilitates data exchange between stakeholders during relief operations. Schniederjans et al. (2016) believe that cloud computing enhances coordination and collaboration between HSC actors. Moreover, it can increase the aid organization agility for improving the most effective and efficient services to the affected areas. Dubey et al. (2018) proved that Big Data Analytics has direct effect on increasing collaboration and swift trust between aid organizations during the disaster time. While Application of Industry 4.0 depends on the case study, in layman's term, prior to using Industry 4.0, there is a dire need to assess the current readiness status of coordination and swift trust based on the most effective Industry 4.0 critical success factors. Such information can better guide decision makers to see the current status of the case study as well as to recognize the weakness and strength of HSC performance. As a result, they can make more logical and practical decision to make the most advantages of Industry 4.0 capabilities. Additionally, the previous studies did not provide any practical advice for 
decision makers based on the specific considered case study for improving coordination and swift trust. The second important research gap is:

- Absence of a study to recognize the readiness status of coordination and swift trust between aid organizations as well as to see the weakness and strength of HSC performance and providing some practical advice for improving coordination and swift trust.

Previous studies mostly applied statistical analysis to see the effect of Industry 4.0 tools on enhancement of HSC performance especially in terms of coordination, flexibility and swift trust. Radriguez-Espindola et al. (2020) proposed a framework for assessing information sharing between stakeholders based on the following factors "Information accuracy", "Procurement process" and "Budget and accountability". Dubey et al. (2019) proved that Big Data Analytics facilitates collaboration between stakeholders and has direct effect on enhancing swift trust. The study has considered the following factors including "Flexible orientation", "Control orientation", "Swift trust" and "Collaborative performance". The studies have proposed their framework based on restricted number of factors and avoid proposing a comprehensive set of factors to see wider dimensions of Industry 4.0 within HSC performance. Another significant research gap is:

- Absence of a framework for assessing wider aspects of Industry 4.0 tools by considering a comprehensive set of critical success factors.

\section{Research methods}

In this research, a novel and unique research methodology is comprised of EFA and Hierarchy Fuzzy Expert System are applied to assess the readiness status of "Swift trust" and "Coordination" for implementation of Industry 4.0 tools aiming improving HSC performance between stakeholders. Since the number of critical success factors are a lot, therefore, it is highly needed to be categorized into meaningful groups for making better decision. EFA is applied to make sure that the critical success factors are effective enough for implementation of Industry 4.0 tools as well as to categorize the factors into limited groups for facilitating further analysis.

Since the critical success factors are categorized into relevant groups, therefore, the assessment of categorized groups should be conducted individually and provide separate output for each group. As a result, based on the number of categorized groups, hierarchy fuzzy expert system is designed to assess the readiness status of HSC for implementing Industry 4.0 tools as well as to provide some practical advice for improving the swift trust and coordination. Moreover, the hierarchy fuzzy expert system can prescribe what Industry 4.0 tool is the most needed one for reaching higher coordination between stakeholders based on the considered case study. Figure 2 shows the research methodology procedure.

\subsection{Designing a questionnaire and its validation}

Following deep literature review, the most critical success factors for implementing Industry 4.0 tools within HSC are extracted from relevant previous studies. The critical success factors for implementing Industry 4.0 tools were collected from the most relevant studies. The factors are able to assess wider aspects of Industry 4.0 implementation within HSC. The factors are 


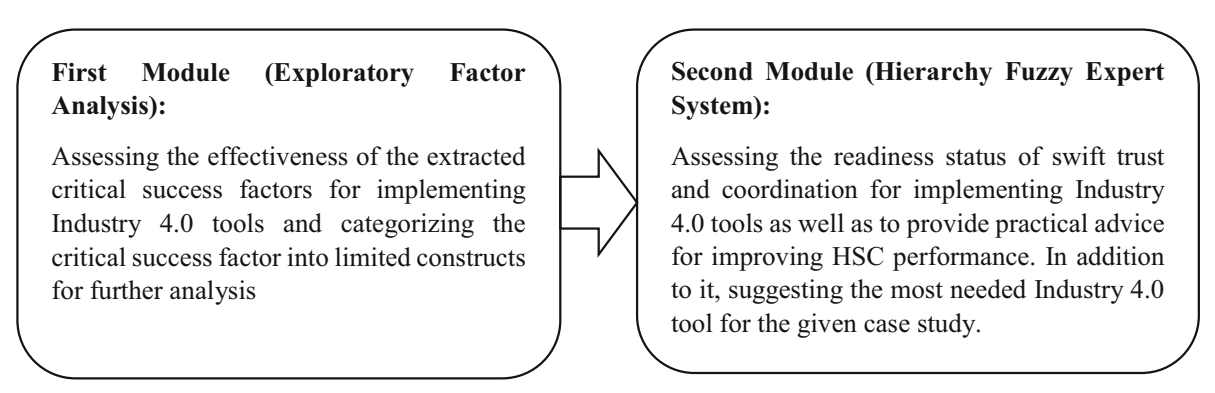

Fig. 2 The research methodology procedure

designed based on Industry 4.0 tools including "Big Data Analytics", "IoT", "Cyber physical system", "Cloud computing" and "Blockchain". Table 3 shows the critical success factors.

In the next step, there is a dire need to make sure that collected factors are the most effective factors for assessing the implementation of Industry 4.0 aiming at increasing HSC performance. In addition to it, due to high number of critical success factors, the factors are supposed to be categorized into limited groups in order to facilitate further analysis. To do so, a questionnaire is designed to collect experts' judgments regarding the effectiveness of selected critical success factors as well as to group the factors into different meaningful constructs.

Initially, a sample questionnaire is designed based-on a 5-point Likert scale from 1 (Very Low) to 5 (Very High). The questionnaire is distributed between five experts to collect their comments regarding the quality of the questionnaire. They were asked to evaluate the quality of designed questions whether they transparently convey the authors message to respondents. The experts also assessed the languages and modified the language for improving the questionnaire content.

After conducting pilot testing, all required modifications following experts' judgments were applied to enhance the questionnaire quality. Finally, the final version of questionnaire was created and was ready to be distributed.

The questionnaire is comprised of two main parts including demographic information of respondents and importance of selected factors based on 5 Likert-scale multiple choices questions.

The collected data are used for assessing the effectiveness of critical success factors on implementing Industry 4.0 aiming enhancing the HSC performance as well as categorizing the most relevant factors into limited constructs.

\subsection{Data collection}

Since one of the recent and common health disasters is the pandemic disease across the world, the current research is designed for the COVID-19 disease. Therefore, the data collection was conducted from relevant organizations to provide relief operations to the affected people during the pandemic disease in Iran.

The respondents were restricted to three main aid organizations during the outbreak of COVID-19. Due to organization privacy, the name of organizations is kept confidential and avoided mentioning their names. The data collection was carried out by distribution of questionnaire and semi-interview meetings. 
Table 3 Critical success factors for implementation of industry 4.0 tools within HSC

\begin{tabular}{|c|c|c|}
\hline Factor & Description & References \\
\hline System Architecture & $\begin{array}{l}\text { It is defined as current system } \\
\text { architecture for supporting } \\
\text { emerging technologies to be } \\
\text { embedded to the current system }\end{array}$ & $\begin{array}{l}\text { Kumar and Singh (2021) and } \\
\text { Yang et al. (2011) }\end{array}$ \\
\hline Cross functional team & $\begin{array}{l}\text { It is defined as employing } \\
\text { multi-skilled people to meet the } \\
\text { requirement of affected people } \\
\text { in early time of disaster }\end{array}$ & $\begin{array}{l}\text { Franke et al. (2021), Kumar and } \\
\text { Singh (2021) and Adesanya } \\
\text { et al. (2020) }\end{array}$ \\
\hline System integration & $\begin{array}{l}\text { It is referred to vertical and } \\
\text { horizontal integration of } \\
\text { existing system in order to } \\
\text { decrease delay response }\end{array}$ & $\begin{array}{l}\text { Kumar and Singh (2021); Yu et al. } \\
\text { (2021); Zhang et al. (2021) }\end{array}$ \\
\hline Financial Transparency & $\begin{array}{l}\text { It is defined as providing the } \\
\text { transparency of financial } \\
\text { records within different aid } \\
\text { organizations engaged with } \\
\text { HSC }\end{array}$ & $\begin{array}{l}\text { Baharmand et al. (2021), Dubey } \\
\text { et al. (2020) and } \\
\text { Rodriguez-Espindola et al. } \\
\text { (2020) }\end{array}$ \\
\hline Strategic planning & $\begin{array}{l}\text { It is referred to monitoring the } \\
\text { data warehouse items to make } \\
\text { sure the traceability of all items } \\
\text { from the origin to the } \\
\text { destination }\end{array}$ & $\begin{array}{l}\text { Agarwal et al. (2020) and Bag } \\
\text { et al. (2020b) }\end{array}$ \\
\hline The mechanism for coordination & $\begin{array}{l}\text { It is defined as creating a structure } \\
\text { and mechanism prior to } \\
\text { outbreak of disaster to provide } \\
\text { better coordination between } \\
\text { stakeholders of HSC }\end{array}$ & $\begin{array}{l}\text { Kumar and Singh (2021); } \\
\text { Agarwal et al. (2020) }\end{array}$ \\
\hline Effective data processing & $\begin{array}{l}\text { It is defined as the ability to } \\
\text { conduct meticulous data } \\
\text { processing for making better } \\
\text { decision }\end{array}$ & $\begin{array}{l}\text { Dubey et al. (2020) and Dubey } \\
\text { et al. (2019) }\end{array}$ \\
\hline Training support & $\begin{array}{l}\text { It is defined as providing } \\
\text { sufficient technical and } \\
\text { non-technical training for } \\
\text { engaged people within relief } \\
\text { operations }\end{array}$ & $\begin{array}{l}\text { Baharmand et al. (2021) and de } \\
\text { Camargo Fiorini et al. (2021) }\end{array}$ \\
\hline $\begin{array}{l}\text { Availability of real-time and } \\
\text { accurate and consistent data }\end{array}$ & $\begin{array}{l}\text { It is defined as having access to } \\
\text { the real-time data of affected } \\
\text { areas and people during the } \\
\text { disaster operations to make } \\
\text { more accurate decision. } \\
\text { Moreover, the data should be } \\
\text { consistent and precise in order } \\
\text { to make better decision }\end{array}$ & $\begin{array}{l}\text { Nagendra et al. (2020) and Seifert } \\
\text { et al. (2018) }\end{array}$ \\
\hline Traceability & $\begin{array}{l}\text { It is referred to tracking the } \\
\text { mobility of all items from } \\
\text { origin to destination and make } \\
\text { sure that the items deliver to the } \\
\text { right affected areas and people }\end{array}$ & $\begin{array}{l}\text { Baharmand et al (2021) and } \\
\text { Dubey et al. (2020) }\end{array}$ \\
\hline
\end{tabular}


Table 3 (continued)

\begin{tabular}{|c|c|c|}
\hline Factor & Description & References \\
\hline Swift trust & $\begin{array}{l}\text { It is referred to establishment of } \\
\text { trust between stakeholders in } \\
\text { order to enhance cooperation } \\
\text { immediately after the outbreak } \\
\text { of disaster }\end{array}$ & $\begin{array}{l}\text { Baharmand et al (2021) and } \\
\text { Dubey et al. (2020) }\end{array}$ \\
\hline $\begin{array}{l}\text { Warehouse and logistic } \\
\text { automation }\end{array}$ & $\begin{array}{l}\text { It is defined as making delivering } \\
\text { and warehousing automatic in } \\
\text { order to decrease the delay of } \\
\text { delivery time to the affected } \\
\text { areas }\end{array}$ & $\begin{array}{l}\text { Ellison and Cook (2020) and } \\
\text { Mushanyuri and Ngcamu } \\
(2020)\end{array}$ \\
\hline Budget and accountability & $\begin{array}{l}\text { It is referred as managing the } \\
\text { stakeholders' responsibility and } \\
\text { behavior during the disaster } \\
\text { period in order to avoid any } \\
\text { potential financial and } \\
\text { accountability corruption }\end{array}$ & $\begin{array}{l}\text { Alem et al. (2021) and Karadağ } \\
\text { et al. (2021) }\end{array}$ \\
\hline Supply Chain resilience & $\begin{array}{l}\text { It is referred as adaptive ability of } \\
\text { supply chain to handle } \\
\text { unpredictable disaster and } \\
\text { provide necessary resources to } \\
\text { the affected areas and } \\
\text { population }\end{array}$ & $\begin{array}{l}\text { Polater (2021) and Dubey et al. } \\
\text { (2020) }\end{array}$ \\
\hline Multiple formats & $\begin{array}{l}\text { It is referred to different formats } \\
\text { of collected data within the data } \\
\text { bases of aid organization. Less } \\
\text { variety of formats leads better } \\
\text { data integration and better } \\
\text { information exchange between } \\
\text { stakeholders }\end{array}$ & $\begin{array}{l}\text { Kumar and Singh (2021) and } \\
\text { Alaswad and Salman (2020) }\end{array}$ \\
\hline Fear of new technology & $\begin{array}{l}\text { Implementation of new } \\
\text { technology requires } \\
\text { fundamental changes of the } \\
\text { current system and recruiting } \\
\text { highly skilled people which } \\
\text { might raise the fear of } \\
\text { employees }\end{array}$ & Jeble et al. (2019) \\
\hline Coordination & $\begin{array}{l}\text { It is referred as coordinating } \\
\text { between aid organizations to } \\
\text { have better collaboration and } \\
\text { accelerate the services delivery } \\
\text { to the affected people and areas }\end{array}$ & $\begin{array}{l}\text { Kumar and Singh (2021) and } \\
\text { Dubey et al. (2020) }\end{array}$ \\
\hline Organizational culture & $\begin{array}{l}\text { It is defined as the common } \\
\text { organization's culture to have } \\
\text { internal coordination and } \\
\text { collaboration to help the } \\
\text { affected people and areas. } \\
\text { Moreover, it also considers } \\
\text { employee's mindset to embrace } \\
\text { such new technologies for } \\
\text { improving the performance }\end{array}$ & $\begin{array}{l}\text { Kumar and Singh (2021) and } \\
\text { Jeble et al. (2019) }\end{array}$ \\
\hline
\end{tabular}


Table 3 (continued)

\begin{tabular}{|c|c|c|}
\hline Factor & Description & References \\
\hline Infrastructure & $\begin{array}{l}\text { It is defined as organization } \\
\text { infrastructure capability to } \\
\text { embed the industry } 4.0 \\
\text { technologies for better delivery } \\
\text { of services to affected area and } \\
\text { people }\end{array}$ & $\begin{array}{l}\text { Negi and Negi (2021) and Patil } \\
\text { et al. (2020) }\end{array}$ \\
\hline Attract funding & $\begin{array}{l}\text { It is referred to the allocated } \\
\text { funding for embedding } \\
\text { emerging technologies to the } \\
\text { existing infrastructure to } \\
\text { enhance the service delivery } \\
\text { quality }\end{array}$ & $\begin{array}{l}\text { Kumar and Singh (2021) and } \\
\text { Ellison and Cook (2020) }\end{array}$ \\
\hline Organizational learning & $\begin{array}{l}\text { Since Industry } 4.0 \text { is an emerging } \\
\text { technology and is required to } \\
\text { experience constant learning, } \\
\text { organizational learning is } \\
\text { defined as keeping the staff with } \\
\text { all required training to enhance } \\
\text { their skills for working with the } \\
\text { new technologies during the } \\
\text { outbreak }\end{array}$ & $\begin{array}{l}\text { Kumar and Singh (2021) and } \\
\text { Jeble et al. (2019) }\end{array}$ \\
\hline Social Media & $\begin{array}{l}\text { It is referred to the use of social } \\
\text { media for getting more } \\
\text { information regarding the latest } \\
\text { status of affected areas and } \\
\text { people. Such information is } \\
\text { handy and accelerate the HSC } \\
\text { performance }\end{array}$ & $\begin{array}{l}\text { Gupta et al. (2019) and Paciarotti } \\
\text { et al. (2021) }\end{array}$ \\
\hline Information security & $\begin{array}{l}\text { It is defined as keeping people's } \\
\text { privacy and avoid abusing such } \\
\text { private information. Moreover, } \\
\text { data encryption avoids data } \\
\text { leakage for further misusing }\end{array}$ & $\begin{array}{l}\text { Patil et al. (2021) and Gupta et al. } \\
\text { (2019) }\end{array}$ \\
\hline Technical skills & $\begin{array}{l}\text { It is referred to required skills for } \\
\text { working with emerging } \\
\text { technologies in order to make } \\
\text { the most advantages of the } \\
\text { technologies aiming at } \\
\text { enhancing HSC performance }\end{array}$ & $\begin{array}{l}\text { Franke et al. (2021), Kumar and } \\
\text { Singh (2021) and Adesanya } \\
\text { et al. (2020) }\end{array}$ \\
\hline
\end{tabular}

To do so, an electronic questionnaire was created and shared with 165 respondents to fill the questionnaire by selecting multiple choices answers. Finally, 65 usable questionnaires were collected from the respondents and the analysis was carried out accordingly. The study was initiated on 10th of May in 2021 and finalized on 8th of June in 2021. The demographic information of respondents was presented in Table 4. 
Table 4 The demographic information of respondents

\begin{tabular}{llll}
\hline Description & & Number & Percentage (\%) \\
\hline Organization name & A & 34 & 52 \\
& B & 21 & 32 \\
Gender & C & 10 & 16 \\
& Female & 12 & 18 \\
Education & Male & 53 & 82 \\
& Bachelor & 35 & 53 \\
\multirow{3}{*}{ Career } & Master & 26 & 40 \\
& PhD & 4 & 7 \\
\multirow{3}{*}{ Work experience } & Senior manager & 6 & 9 \\
& Coordinator & 47 & 72 \\
& General Practitioner & 12 & 18 \\
& Less than 5 years & 21 & 32 \\
& Between 5 and 10 years & 34 & 52 \\
\hline
\end{tabular}

\subsection{Data analysis}

To Verify whether the selected factors are the most effective ones for implementing Industry 4.0 tools aiming at improving HSC performance, an empirical study was conducted to check the efficiency of the critical success factors. In the first step, the reliability of the entire collected data was carried out by calculating Cronbach Alpha whose value should exceed 0.7 (Yap et al., 2020). The Cronbach Alpha for the current research was calculated 0.821. The result denotes that the collected data is highly valid and reliable for further mathematical and statistical analysis.

In the next step, EFA is applied for the current research to unveil potential correlations between different unrelated factors (Makkar \& Singh, 2018). IBM SPSS Statistics 25 software is used for analysing empirical data. EFA was conducted to group the verified factors into limited constructs. The EFA method groups the most relevant factors into limited constructs and facilitates the further analysis. Prior to applying EFA, sample size adequacy is highly required by calculation of KMO and Bartlett's test of sphericity methods whose value should be greater than 0.5 and be significant $(p<0.05)$ respectively (Aggarwal \& Singh, 2020). The $\mathrm{KMO}$ value was resulted in 0.725 and Barlet's test was significant since its $p$ value was 0.000 and lower than 0.05 .

The EFA is applied by Principal Component Analysis (PCA) with VARIMAX rotations. Applying the PCA and VARIMAX rotations and Eigenvalue greater than one makes 5 groups with a total of $75.90 \%$ variance (Which should be greater than the minimum value variance of $60 \%$ for satisfactory factor analysis) (Yap et al., 2020). Figure 3 and Table 5 show the EFA research methodology procedure and the loading factors and the variance value respectively.

As it is shown in Table 5, all loading factors value are greater than the threshold (0.4) which are accepted as the most effective factors (Asghar et al., 2020). After that the crossloading factor are checked in order to make sure that each factor is considered under single construct, otherwise, they are omitted from the list. All loading factors appear only on one 


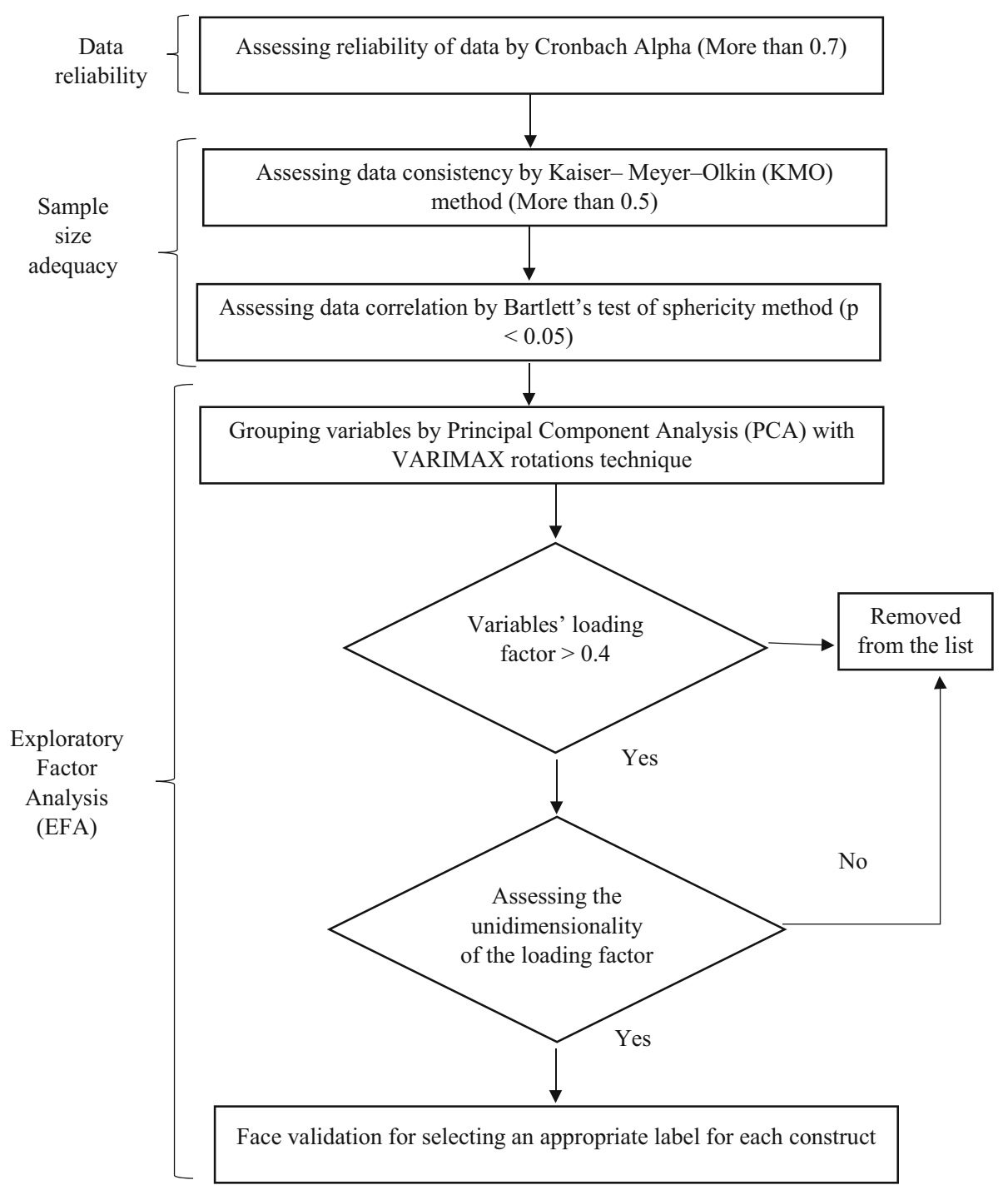

Fig. 3 EFA research methodology procedures

construct which are going to be accepted as reliable factors. In addition to it, Cronbach Alpha is calculated for each construct whose value should be greater than the threshold (0.7). The Cronbach value ranges from 0.721 to 0.874 to check internal consistency within each relevant construct. After categorizing all relevant factors by applying PCA and Rotation Varimax to categorize the factors into the most relevant groups, face validation is needed to assign an appropriate name to better interpret the concept of each construct for researchers. 
Table 5 Final results

\begin{tabular}{|c|c|c|c|}
\hline Construct & Factors & Loading factor & Variance \\
\hline \multirow{5}{*}{$\begin{array}{l}\text { Logistic } \\
\qquad(\alpha=0.756)\end{array}$} & Strategic planning & 0.856 & \multirow[t]{5}{*}{18.28} \\
\hline & Warehousing and logistic & 0.821 & \\
\hline & Mechanism for coordination & 0.801 & \\
\hline & Attract funding & 0.796 & \\
\hline & Budget and accountability & 0.713 & \\
\hline \multirow{5}{*}{$\begin{array}{l}\text { Learning } \\
\qquad(\alpha=0.824)\end{array}$} & Organizational culture & 0.891 & \multirow[t]{5}{*}{17.35} \\
\hline & Organizational learning & 0.874 & \\
\hline & Training support & 0.852 & \\
\hline & Cross functional team & 0.823 & \\
\hline & Technical skills & 0.789 & \\
\hline \multirow{3}{*}{$\begin{array}{l}\text { Transparency } \\
(\alpha=0.796)\end{array}$} & Traceability & 0.865 & \multirow[t]{3}{*}{14.32} \\
\hline & Financial transparency & 0.841 & \\
\hline & Social media & 0.823 & \\
\hline \multirow{4}{*}{$\begin{array}{l}\text { Information Quality } \\
\qquad(\alpha=0.874)\end{array}$} & Availability data processing & 0.836 & \multirow[t]{4}{*}{13.63} \\
\hline & Information reliability and consistency & 0.811 & \\
\hline & Effective data processing & 0.803 & \\
\hline & Information security & 0.783 & \\
\hline \multirow{3}{*}{$\begin{array}{l}\text { Infrastructure } \\
\qquad \alpha=0.721)\end{array}$} & System architecture & 0.897 & \multirow[t]{3}{*}{12.32} \\
\hline & System integration & 0.856 & \\
\hline & Technical infrastructure & 0.803 & \\
\hline
\end{tabular}

\subsection{Hierarchy fuzzy expert system}

Fuzzy sets theory is a common methodology to model the existed imprecision within real world problems. Fuzzy sets theory enables researchers to create more realistic representation of real problem with simplicity. The method can be applied with different statistical and mathematical formulation to capture the inherent vagueness within the given problems and existed imprecision of experts' judgments (Xu et al., 2019). All required mathematical calculation is presented in Appendix 1.

Fuzzy expert system is a non-linear system which operates based on IF-THEN rules inserted in the knowledge base to model qualitative aspect of human judgments. Since, the input and output of the fuzzy expert system is designed based linguistic variables. Therefore, the system is interactive for users to conduct the most complicated assessment. The fuzzy expert system is comprised of four main modules including: "Fuzzification", "Knowledge Base", "Defuzzification" and Inference Engines" (Hamedan et al., 2020). The Fig. 4 shows the main modules of fuzzy expert system.

The crisp data is taken from the real world and is converted to into fuzzy number. The fuzzy number enters to the fuzzy inference engine and based on the collected knowledge with in Knowledge base, fuzzy output is created. Finally, the fuzzy output is supposed to be defuzzied in order to be understandable for users. 


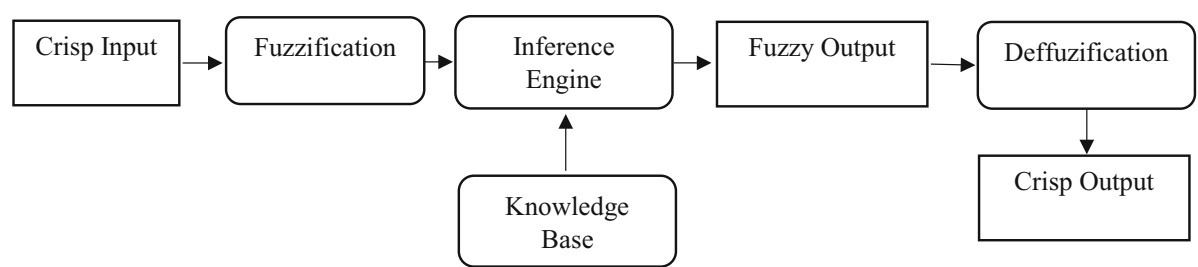

Fig. 4 Fuzzy expert system modules

Since the number of critical success factors are numerous and creating one expert system is so complicated, therefore, hierarchy fuzzy expert system is suggested analyzing the critical success factors in independent fuzzy expert system. One fuzzy expert system is allocated and designed for each categorized construct.

In the first layer of hierarchy fuzzy expert system, the fuzzy expert system is intended to be designed in order to assess the readiness status of coordination and swift trust within HSC performance. The designed system can easily show the readiness status of coordination and the level of swift trust in any given HSC case studies. Moreover, the recommended system can provide some practical advice for improving swift trust and coordination between entities during the relief operations. Additionally, the fuzzy expert system can equip managers with some practical advice for improving the HSC performance.

In the second layer, swift trust and coordination are considered as input of next layer of fuzzy expert system. The designed fuzzy expert system is able to suggest the most effective and practical Industry 4.0 tools (including "Big Data", "IoT", "Blockchain", "Cloud computing" and "Cyber physical system"). The system prioritizes the industry 4.0 tools based on given case study for improving coordination and swift trust as well as to improve HSC performance. Figure 5 shows the hierarchy fuzzy expert systems.

\section{Case study}

The proposed framework is applied for three aid organizations in Iran. The aid organizations are responsible for providing medical health assistance within the disaster period. Recently, the organizations were accountable for providing medical health during the pandemic. The organizations have around 230 staffs providing preliminary medical assistance to the affected people. The companies are considered as semi-stated organizations with more than 42-years experience. Due to keeping company's privacy, we avoid mentioning the organization's name. The framework is supposed to assess the readiness status of coordination and swift trust of three aid organizations which are responsible for providing medical support for the affected people during the pandemic period in Iran. Since the fuzzy expert system is supposed to provide some practical advice within each construct, it is highly required to clarify the input and output of fuzzy expert system. Table 6 shows the input and output of fuzzy expert system.

In order to collect experts' judgments for the knowledge base of fuzzy expert system, 6 personals were selected from the three organizations and were asked to hold face-to-face meetings in order to collect their judgments regarding the association rules between critical success factors. The experts were asked to separately leave their comments regarding each relevant critical success factors for each construct individually. In addition to that, they were asked to leave their comments about membership function of fuzzy expert system's inputs and 


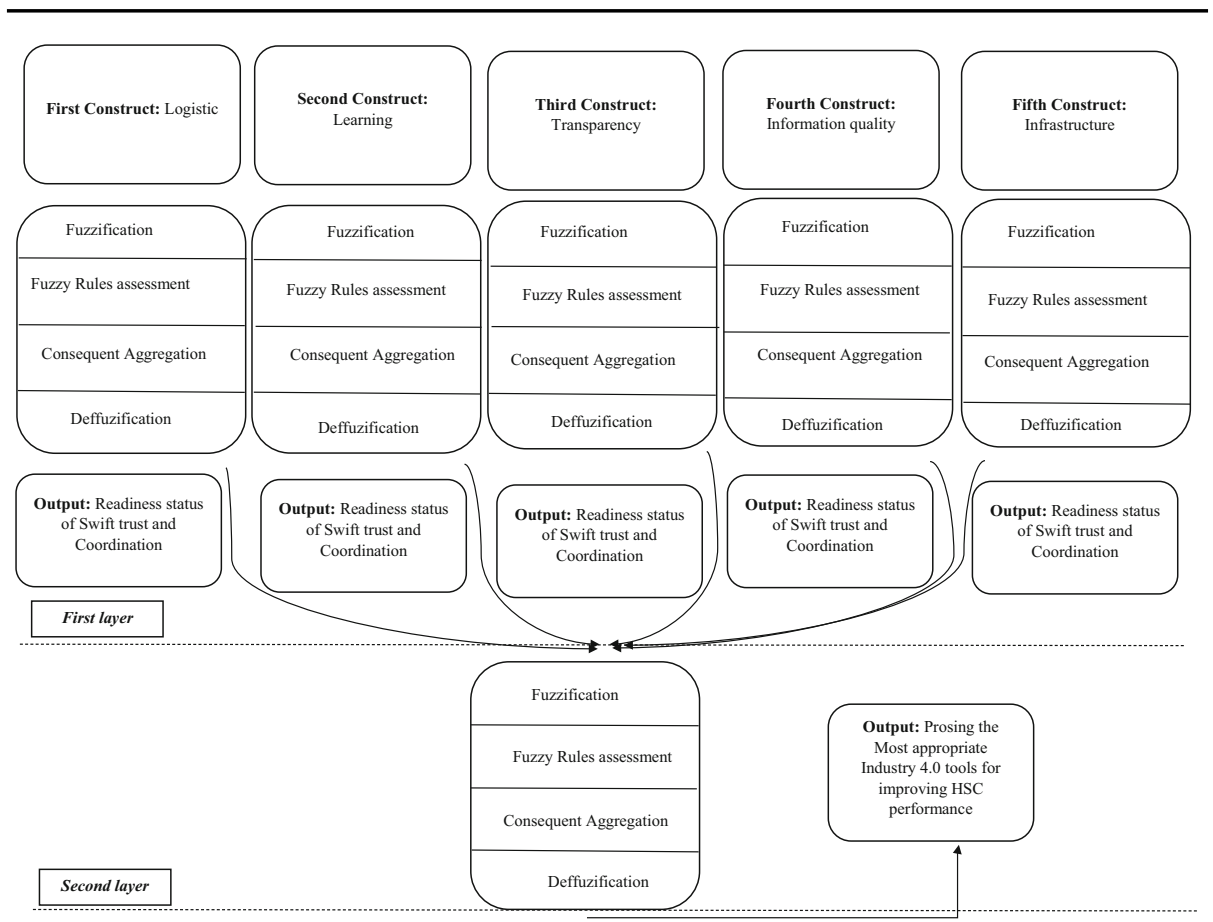

Fig. 5 Hierarchy fuzzy expert systems

Table 6 The input and output of fuzzy expert systems

\begin{tabular}{llc}
\hline Construct & Input & Output \\
\hline Logistics fuzzy expert system & Strategic planning & Swift trust \\
& Mechanism for coordination & Coordination \\
& Budget and accountability & Strategic planning \\
& & Attract funding \\
Learning fuzzy expert system & Training support & Swift trust \\
& organizations learning & Coordination \\
& Technical skills & Organization \\
& Organizational culture & learning \\
& & Cross functional \\
Transparency fuzzy expert system & & team \\
& Financial transparency & Swift trust \\
& Traceability & Coordination \\
Information quality fuzzy expert system & Social Media & Tracking system \\
& Effective data processing & Swift trust \\
& Availability of data processing & Coordination \\
& Information security & Decreasing data \\
& Information reliability and & format \\
Infrastructure fuzzy expert system & consistency & \\
& System architecture & Swift trust \\
& System integration & Coordination \\
& Technical infrastructure & Integrating between \\
& & databases
\end{tabular}




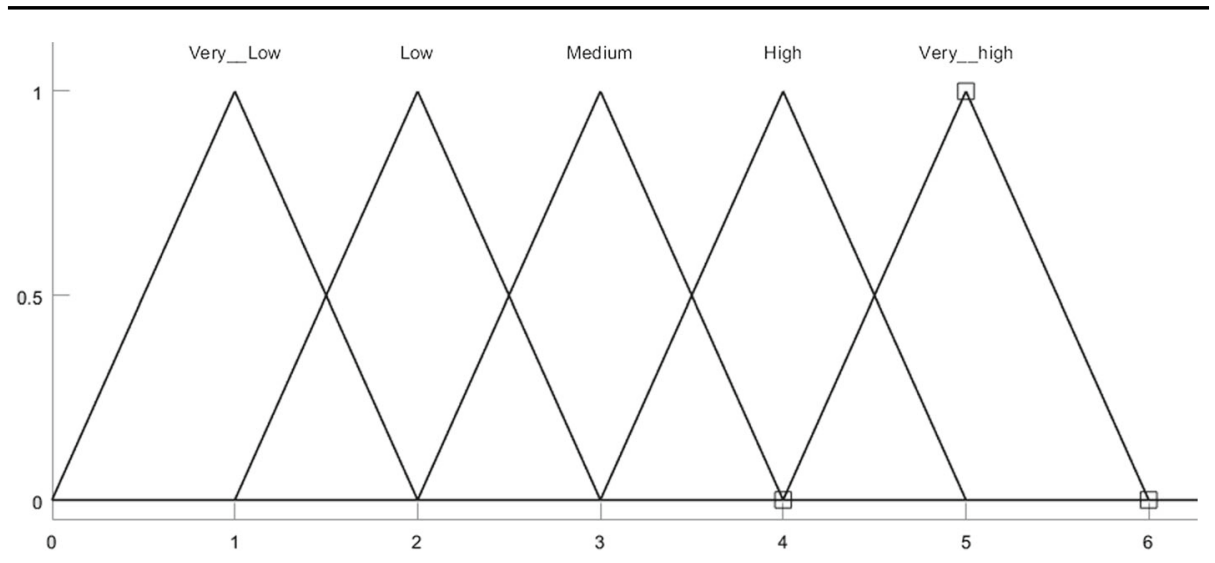

Fig. 6 Membership function of system integration

Table 7 Readiness value

\begin{tabular}{lllll}
\hline Construct & Swift Trust & Linguistic variables & Coordination & Linguistic variables \\
\hline Logistic & $(3.8,4.6,5.4)$ & High & $(3.12,3.6,4.2)$ & High \\
Infrastructure & $(0.8,1.26,2.3)$ & Low & $(2.2,2.9,3.4)$ & Medium \\
Transparency & $(3.4,4.2,4.8)$ & High & $(3.2,4.3,5.2)$ & High \\
Information quality & $(0.2,1.2,2.3)$ & Very low & $(0.4,0.8,2.3)$ & Very low \\
Learning & $(1.8,3.2,4.1)$ & Medium & $(2.3,3.2,4.6)$ & Medium \\
\hline
\end{tabular}

outputs. Their comments were collected and a unique membership function was allocated for each critical success factor. Figure 6 shows the membership function of system integration.

After designing the fuzzy expert systems, 12 personals were selected from the aid organizations to leave their comments regarding the fuzzy expert system inputs using linguistic variables including "Very high", "High", "Medium", "Low" and "Very low". In the first layer of hierarchy fuzzy expert system, the output shows the readiness status of coordination and swift trust within HSC. Table 7 and Fig. 7 shows the readiness status in five categorizations.

As it is shown within the Table 7 and the Fig. 7, the logistics performance was assessed "High" which shows high readiness within the HSC network. There is strong coordination mechanism for delivering medical support for the affected people. Moreover, a strong strategic planning was implemented between the aid organizations to check the mobility of items within HSC network.

Transparency is also assessed with high readiness value showing that information exchange between the organizations is reasonable due to implementing a strong traceability information system between all aid organizations. The traceability system helps decision makers to see the track of all items within HSC network and make sure that all items are delivered to the affected people.

Learning is the third assessed construct whose readiness is medium. Poor learning culture within staff decreases staff willingness to learn more about emerging technologies. Another reason is low level of holding regular workshops for staff to expose them to application of Industry 4.0 tools. 

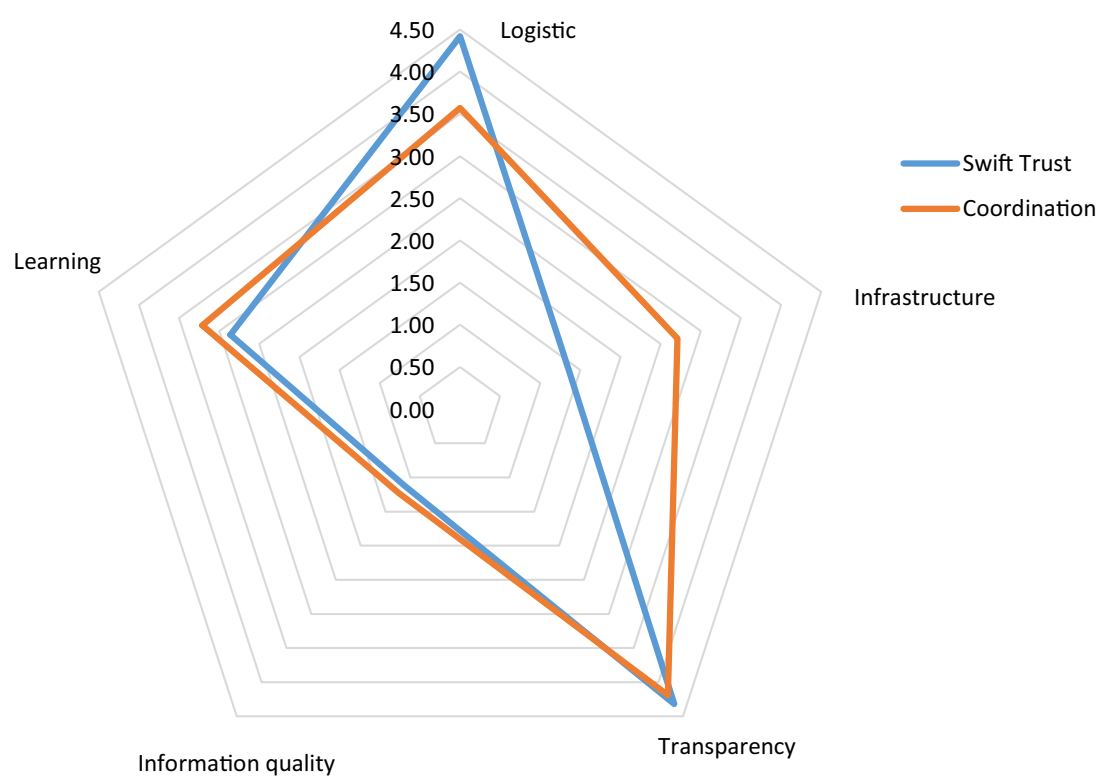

Infrastructure

Fig. 7 The readiness status of swift trust and coordination

The assessment shows that Infrastructure readiness level is "medium" for the aid organizations. The current system architecture is not compatible with emerging technologies aiming at creating an integrated system for better information exchange. But the technical infrastructure such as preliminary platform for basic telecommunication is reasonably high.

Information quality readiness status is "very low" which denotes that the aid organizations do not follow up a common data format. Various data format hampers the ease of information sharing between the organization's databases regarding the affected people and areas.

Table 8 shows the practical advice for decision makers for improving the HSC performance within each construct.

As it is explained, the first layer of fuzzy expert systems shows the readiness status of swift trust and coordination for the considered HSC network. Moreover, the system provided valuable advice for the managers for improving the coordination and swift trust based on the fuzzy expert system's input for the given case study.

In the second layer, the output of first layer is considered as the input of the second layer. The final output prioritizes the most essential Industry 4.0 tools including "Big Data Analytics", "IoT", "Cyber physical system", "Cloud computing" and "Blockchain" for improving the HSC performance.

The second layer of hierarchy fuzzy expert systems is designed based on Industry 4.0 tools and the output is presented by linguistic variables from "Strongly important" to "Not Strongly Important". Table 9 shows the final outcome.

As it is shown within the Table, the aid organizations are supposed to consider IoT as the most needed Industry 4.0 tool for improving coordination and swift trust between stakeholders. IoT can facilitate reaching to more reliable data taken out by different sensors or applications to present the latest status of items and affected people. Such data leads to higher transparency and better information sharing between HSC actors. The second recommended tool is Big Data Analytics which creates better analysis of information to make more logical 
Table 8 Practical advice for improving HSC performance

\begin{tabular}{l} 
Construct \\
Recommended advice \\
\hline Logistic \\
$\begin{array}{l}\text { There is a dire need to attract more funding to improve mechanism coordination for } \\
\text { better recognition of responsible aid organizations within relief operations } \\
\text { The aid organizations are required to create integrated databases to improve more } \\
\text { data integrity between stakeholders } \\
\text { The aid organizations should apply tracking system in order to better envision the } \\
\text { traceability of items within HSC network as well as online tracking of items from } \\
\text { the origin to the destination in order to avoid any potential abuse } \\
\text { It is highly recommended for the aid organization to work on the data formats and } \\
\text { try to provide a single data format in order to provide more compatibility between } \\
\text { databases and allowing faster information sharing between stakeholders during } \\
\text { the disaster period } \\
\text { It is recommended for the aid organization to work on the organizational learning } \\
\text { through equipping the staff and employees with practical workshops aiming at } \\
\text { exposing them with the most cutting-edge technologies and decrease the fear of } \\
\text { new technologies }\end{array}$ \\
Learning
\end{tabular}

Table 9 The final outcome of the second layer of hierarchy fuzzy expert system

\begin{tabular}{lllll}
\hline Industry 4.0 tools & Fuzzy number & Crisp number & Priority number & Linguistic variable \\
\hline Cloud computing & $(1.7,2.8,3.9)$ & 2.76 & 4 & Medium \\
IoT & $(5.7,6.2,6.9)$ & 6.31 & 1 & Strongly important \\
Blockchain & $(4.1,5.1,5.9)$ & 5.12 & 3 & Important \\
Big data analytics & $(5.3,6.3,6.7)$ & 6.11 & 2 & Strongly important \\
Cyber physical system & $(0.2,1.2,2.9)$ & 1.29 & 5 & Not strongly important \\
\hline
\end{tabular}

decision. The tool provides a descriptive and predictive dashboard for decision makers to better see the entire HSC network and make more practical decision.

\subsection{System robustness}

After applying the framework for the considered case study. The result is supposed to be shared within the experts to show their satisfactory comments regarding the validity and reliability of the framework. Five experts from three different aid organizations were selected to give their satisfactory rate out of 100 . They have more than seven years' experience in HSC as well as to work in different aid organizations in Iran. The experts' positions are senior managers within state and semi-state organizations. Table 10 shows the average rate of expert's satisfaction.

As it is presented in Table 10, the vast majority of experts show their satisfaction regarding the final outcome of the framework. Such results show the reliability and high accuracy of the framework which can be extended for other HSC network for assessing the readiness status of construct as well as to recommend the most prioritized and efficient Industry 4.0 tools for improving HSC performance and relief operations. 
Table 10 Average satisfaction rate

\begin{tabular}{|c|c|c|c|}
\hline $\begin{array}{l}\text { Construct (first } \\
\text { layer) }\end{array}$ & $\begin{array}{l}\text { Average } \\
\text { satisfaction } \\
(\%)\end{array}$ & $\begin{array}{l}\text { Industry } 4.0 \\
\text { tools (second } \\
\text { layer) }\end{array}$ & $\begin{array}{l}\text { Average } \\
\text { satisfaction } \\
(\%)\end{array}$ \\
\hline Logistic & 92 & $\begin{array}{l}\text { Big data } \\
\text { analytics }\end{array}$ & 88 \\
\hline Infrastructure & 91 & $\begin{array}{l}\text { Cloud } \\
\text { computing }\end{array}$ & 86 \\
\hline Transparency & 88 & IoT & 92 \\
\hline $\begin{array}{l}\text { Information } \\
\text { quality }\end{array}$ & 96 & $\begin{array}{l}\text { Cyber physical } \\
\text { system }\end{array}$ & 90 \\
\hline Learning & 84 & Blockchain & 93 \\
\hline
\end{tabular}

\section{Discussion}

The study proposes a novel framework for assessing two main challenging issues of HSC including "Swift trust" and "Coordination" aiming at enhancing the performance of HSC during the outbreak of disaster. The study has proposed a unique hybrid research methodology using both empirical study and hierarchy fuzzy expert system. The final result shows both theoretical contributions and practical implications for improving HSC performance.

\subsection{Theoretical implications}

The study proposes a framework for assessing the critical success factors for implementation of Industry 4.0 aiming at enhancing the "Coordination" and "Swift trust". The study has conducted extensive and meticulous literature review to extract a comprehensive set of factors to assess wider aspects of HSC network. The study introduces 29 factors which is able to increase the manager's vision over the entire status of HSC network. The factors are categorized into limited groups in order to better understand the different aspects of HSC performance. The outcome unveils five constructs including "Logistics", "Infrastructure", "Transparency", Information quality" and "Learning". Such categorization is so extensive and enable decision makers to see wider dimensions of HSC performance. While previous studies mostly considered limited aspects of HSC performance. For instance, Kumar and Singh (2021) unveiled a set of critical success factors for implementation of Industry 4.0 in HSC. While the study concentrated on limited aspects of HSC including Infrastructure, Data quality and training. Nagendra et al. (2020) explored the critical role of big data analytics for improving data accuracy and reliability at the outbreak of disaster. The study considered data quality and traceability of items within the HSC network. Jeble et al. (2019) investigated the important role of big data analytics on enhancement of HSC performance. The study focused on the data quality and learning as the main critical success factors for implementation of Industry 4.0. As it is explained, the previous studies' perspective toward the implementation of Industry 4.0 within HSC is so limited while the current study proposes five categorizations under 29 critical success factors which provide more comprehensive framework comparing to the previous studies.

The most important tools of Industry 4.0 are "Big Data", "IoT", "Blockchain", "Cloud computing" and "Cyber physical system" and each tool can cause particular benefit and advantage to HSC performance (Dubey et al., 2020; Kumar \& Singh., 2021). The previous 
studies only consider one of the Industry 4.0 tool and assess the its effect on increasing the quality of relief operations. Sharma and Joshi (2020) have investigated the significant effect of Big Data Analytics for improving HSC performance. The study restricted the concept of Industry 4.0 to the role of Big Data Analytics on increasing relief operations. Dubey et al. (2020) have proposed a framework for enhancing swift trust and coordination within HSC aiming at reaching to HSC resilience. The study concentrates on the significant impact of blockchain for improving HSC performance and relief operations. While the current study has considered all Industry 4.0 tools including "Big Data", "IoT", "Blockchain", "Cloud computing" and "Cyber physical system" for improving swift trust and coordination. Such issue makes a strong contribution to HSC network by getting benefits from all Industry 4.0 tools capabilities within the network.

The research extends OIP theory by analyzing and processing all relevant information to HSC network and providing valuable information to decision makers for making better and logical decision aiming at enhancing HSC reliance. Such information causes the aid organizations to grab competitive advantages and perform more efficiently and practically for serving the affected people and areas.

The study result denotes that logistic is the most significant construct with highest variance value of $18.28 \%$. The construct mostly concentrates on the mobility of items from the origin to the destination and make sures that all required services are served efficiently to the affected people. The Strategic planning is computed as the most important critical success factors for implementing Industry 4.0 tools within relief operations. Kumar and Singh (2021) also supported such idea and denoted that strategic planning is the most important factor for implementation of Industry 4.0. Warehousing is the second important factor which focuses on automation of item delivery from origin to the destination. Such factor is highly important for better implementation of Industry 4.0 and make the Industry 4.0 tools be embedded more easily and smoothly to the existing system. Kumar and Singh (2021) also support the factor for better implementation of Industry 4.0.

The second important construct is learning with the variance value of $17.35 \%$. The construct emphasizes on improving learning and training within inside and outside aid organizations for providing more efficient relief operation for the affected population. The first and fundamental factor is organizational culture which is responsible for increasing employees' intentions and willingness to upgrade their information and knowledge regarding different aspects of Industry 4.0 tools. Such issue has direct impact on increasing employee's compatibility with new technology and decreasing the fear of cutting edge-technology. Jeble et al. (2019) has highlighted the important role of organizational culture for improving data-driven decision of managers while our study focuses on the other aspect of organizational culture to enhance employees' interest in learning without external pressure. Training support is also calculated as another important factor to expose staff to workshops and training courses for increasing staff's familiarity with new technologies. Kumar and Singh (2021) also underlined the significant role of training for increasing their information regarding the application of Industry 4.0 at the outbreak of disaster.

Transparency is the third important construct with the variance value of $14.32 \%$. The construct provides higher information transparency of aid organizations and affected areas. Such transparency is so beneficial for better coordination of aid organizations during the disaster period. The most important factor is traceability which refers to following up all items, services and operations meticulously and make sure that the services and items are delivered to the right area and population. The critical role of traceability is also mentioned by Kumar and Singh (2021) as a strong tool for improving relief operations and provide the best services to the needy people in the affected area. Social media is also mentioned 
as another important critical success factor for pursuing the affected people and area. Since social media is a commonplace communication tool among all people, it can be considered as reliable channel to get the latest updated information from affected population and deliver required services to them. Gupta et al. (2019) did emphasize on the significant role of social media for streamlining relief operations and efforts.

The fourth important construct is information quality with the variance value of $13.63 \%$. The construct focuses on the creating a common data format for providing integrated data for better information exchange between aid organizations during the disaster period. The first issue is availability of data for processing in order to reach valuable information aiming at making better decision. The second important issue is that the available data should be reliable to do further analysis otherwise the outcome cannot be used for making decision. Sinha et al. (2019) strongly believe that data consistency and reliability is so crucial for improving HSC performance by reaching to real-time and consistent data using IoT. Keeping all information private and avoid leakage during the disaster period is highly important to prevent abusers from misusing the information by accessing to private information. Gupta et al. (2019) also highlighted keeping information privacy and security by encrypting algorithm and methods.

The last important construct is Infrastructure with the variance value of $12.32 \%$. The construct assesses the required infrastructure for implementing industry 4.0 tools within existed system. The first important factor is system architecture which evaluates the existing architecture for making compatibility with the emerging technologies. Moreover, the factor proposes required actions for facilitating integration with Industry 4.0 tools. Kumar and Singh (2021) prove that system architecture is so essential for supporting new technologies such as IoT and RFID as the third important factor while our study proves that system architecture is the most important factor as infrastructural element for adapting to emerging technologies. The second important factor is system integration which is another important infrastructural practice to make all aid organizations databases integrate together and enable faster information exchange as well as reaching to higher data accuracy and consistency. Kumar and Singh (2021) also proved that system integration is the sixth important element for implementing Industry 4.0 while our study considers the factor as the second most significant element.

\subsection{Practical implications}

The framework provides practical implications for decision makers and managers of aid organizations to make more efficient decision for improving HSC performance. The study provides a descriptive and prescriptive dashboard for decision makers to see the readiness status of HSC network as well as to spot weakness and strength of entire supply chain. Such information can help decision makers easily make a right decision for improving the performance and provide the most efficient services and support for the affected people.

The proposed framework is designed to propose the most required Industry 4.0 enablers including IoT, Big Data, Blockchain, Cloud computing and Cyber physical system to enhance the coordination and swift trust. The proposed framework is carried out for Iranian cases study during the COVID-19 disease.

The main practical lesson which managers should consider with the HSC performance is Information quality. The managers are supposed to create a secure and safe platform for cleaning the data and make sure that the data is reliable and provide trustable insight to decision makers. One of the best ways in order to provide such information is application of IoT for accumulating reliable data from sensors and actuators within the environment and 
affected areas. Sinha et al. (2019) highlighted the role of IoT in better creation of coordination between actors through faster data collection by implementation of actuators. The study was conducted for the case of natural disaster. The study outcome highlights the importance of IoT for making more accurate decision.

Managers are expected to provide learning environment within aid organizations to expose staff to efficient training and workshops in order to equip them with all required skills and information during the disaster time. Learning environment can enhance organizations culture with the passage of the time and enables staffs to easily improve their capability such as better coordination and swift trust. Kabra et al. (2017) considered learning culture as one of the critical factors for enhancing HSC performance during disaster period. The study also attracted managers attention to improve learning culture within the organization for improving efficiency of relief operations.

Practically speaking, implementing all Industry 4.0 tools simultaneously is time consuming and cost a fortune for aid organizations to be implemented, therefore, the framework can easily propose the most needed Industry 4.0 tool for considered case study. Such outcome is so beneficial for aid organizations to increase the service efficiency and saving a lot of time, energy and cost.

\section{Conclusion}

Unpredictable disasters have highlighted the importance of HSC during the outbreak to serve the most affected people and area. Since there are number of actors within HSC, creating coordination between all actors is so complicated during the disaster period. In addition to that, having swift trust between actors at the outset of disaster is highly required to enable the actors to collaborate and work together for relief operations.

Therefore, the main challenges of providing efficient relief operations are creating "swift trust" and "coordination" during the relief operations. One of the appropriate ways for facilitating the swift trust and coordination is application of Industry 4.0. The study intends to propose the most important critical success factors for implementation of Industry 4.0 within HSC.

The most relevant factors are extracted from previous studies and validated by empirical studies and are grouped into limited constructs including "logistic", "learning", "transparency", "Information quality" and "Infrastructure" using EFA method.

In the next step, a hierarchy fuzzy expert system is designed in order to assess the readiness status of the two following concepts including swift trust and coordination as well as proposing the most needed and suitable industry 4.0 application for the given case study.

The framework was applied for aid organizations in Iran responsible for providing medical assistance during COVID-19 to determine the readiness status of coordination and swift trust concepts as well as recommending the most needed Industry 4.0 applications for the organizations. The result determines that logistic and transparency received highest readiness value while information quality received the lowest readiness value. The framework also suggests that the organizations should invest on two most important Industry 4.0 applications including "IoT" and "Big Data Analytics" in order to enhance coordination and swift trust during relief operations.

Additionally, the study has extended the OIP theory within HSC aiming at getting competitive advantages by analyzing and processing organizational information. 


\section{Limitations and future scope of research}

In this study, a general framework for assessing the HSC performance is suggested. The framework operates as dashboard for decision makers and managers for making more logical and effective decision. While the input and output of the framework is implemented by experts' judgments which is a little time consuming and less accurate. It is highly recommended to make the framework more automatic and faster by application of data mining algorithm to be applied within aid organizations databases. The outcome is more reliable and more accurate and provide more logical results for decision makers.

\section{Appendix 1}

See Table 11 .

Table 11 Mathematical operations

\begin{tabular}{lll}
\hline No & Operation & Outcome \\
\hline 1 & Sum & $A+B=\left(a_{1}, a_{2}, a_{3}\right)+\left(b_{1}, b_{2}, b_{3}\right)=\left(a_{1}+b_{1}, a_{2}+b_{2}, a_{3}+b_{3}\right)$ \\
2 & Subtraction & $A-B=\left(a_{1}, a_{2}, a_{3}\right)-\left(b_{1}, b_{2}, b_{3}\right)=\left(a_{1}-b_{2}, a_{2}-b_{2}, a_{3}-b_{1}\right)$ \\
3 & Multiplication & $A \times B=\left(a_{1}, a_{2}, a_{3}\right) \times\left(b_{1}, b_{2}, b_{3}\right)=\left(a_{1} \times b_{1}, a_{2} \times b_{2}, a_{3} \times b_{3}\right)$ \\
4 & $\begin{array}{l}\text { Positive crisp number (p) } \\
\text { multiplication }\end{array}$ & $p \times\left(a, a_{2}, a_{3}\right)=\left(k \times a_{1}, k \times a_{2}, k \times a_{3}\right)$ if p p $>0$ \\
& $\begin{array}{l}\text { Negative crisp number (p) } \\
\text { multiplication }\end{array}$ & $p \times\left(a, a_{2}, a_{3}\right)=\left(k \times a_{3}, k \times a_{2}, k \times a_{1}\right)$ if $p<0$ \\
& &
\end{tabular}

Definition 1: If $\tilde{A}$ is a fuzzy set, fuzzy member is defined by a membership function $\mu_{\tilde{A}}(x)$ allocating a value from zero to one. The greater value (closer to one) denotes stronger belonging to the fuzzy set $\tilde{A}$.

$$
\tilde{A}=\left\{\left(x, \mu_{\tilde{A}}(x) \mid x \in X\right\}\right.
$$

where $X$ is a universal set and $\mu_{\tilde{A}}(x): X \rightarrow[0,1]$

Definition 2: Fuzzy number is a subset of fuzzy set in the universe of discourse $X$. It is normalized and convexed. Trapolized $A=\left(a_{1}, a_{2}, a_{3}, a_{4}\right)$ and triangular $B=\left(a_{1}, a_{2}, a_{3}\right)$ are the common fuzzy numbers whose membership functions are delineated by:

$$
\begin{gathered}
\mu_{\tilde{A}}(x)= \begin{cases}\frac{x-a_{1}}{a_{2}-a_{1}}, & m_{1} \leq x \leq m_{2} \\
1, & m_{1} \leq x \leq m_{2} \\
\frac{a_{4}-x}{a_{4}-a_{3}}, & m_{1} \leq x \leq m_{2} \\
0, & \text { otherwise }\end{cases} \\
\mu_{A}(x)=\left\{\begin{array}{lll}
\frac{x-a_{1}}{a_{2}-a_{1}} & \text { if } & a_{1} \leq x \leq a_{2} \\
\frac{a_{3}-x}{a_{3}-a_{2}} & \text { if } & a_{2} \leq x \leq a_{3} \\
0 & \text { Other }
\end{array}\right.
\end{gathered}
$$


Definition 3: The most common mathematical operations for two triangular fuzzy numbers $A=\left(a_{1}, a_{2}, a_{3}\right)$ and $B=\left(b_{1}, b_{2}, b_{3}\right)$.

Definition 4: Fuzzy triangular number $\tilde{B}=\left(b_{1}, b_{2}, b_{3}\right)$ is deffuzified using:

$$
\operatorname{Deff}(\tilde{B})=\frac{b_{1}+b_{2}+b_{3}}{3}
$$

\section{References}

Adesanya, A., Yang, B., Bin Iqdara, F. W., \& Yang, Y. (2020). Improving sustainability performance through supplier relationship management in the tobacco industry. Supply Chain Management, 25(4), 413-426.

Agarwal, S., Kant, R., \& Shankar, R. (2020). Evaluating solutions to overcome humanitarian supply chain management barriers: A hybrid fuzzy SWARA—fuzzy WASPAS approach. International Journal of Disaster Risk Reduction. https://doi.org/10.1016/j.ijdrr.2020.101838

Aggarwal, S., \& Singh, A. K. (2020). Developmental, relational and facilitating (DRF) Organizational Culture Scale: An Empirical Study in Select Colleges of University of Delhi. Global Business Review. https:// doi.org/10.1177/0972150920939761

Alaswad, S., \& Salman, S. (2020). Humanitarian aid and relief distribution (HARD) game. Advances in Engineering Education, 8(2), 1-30.

Alem, D., Bonilla-Londono, H. F., Barbosa-Povoa, A. P., Relvas, S., Ferreira, D., \& Moreno, A. (2021). Building disaster preparedness and response capacity in humanitarian supply chains using the Social Vulnerability Index. European Journal of Operational Research, 292(1), 250-275.

Asghar, I., Cang, S., \& Yu, H. (2020). An empirical study on assistive technology supported travel and tourism for the people with dementia. Disability and Rehabilitation: Assistive Technology, 15(8), 933-944.

Bag, S., Gupta, S., \& Wood, L. (2020a). Big data analytics in sustainable humanitarian supply chain: Barriers and their interactions. Annals of Operations Research. https://doi.org/10.1007/s10479-020-03790-7

Bag, S., Luthra, S., Venkatesh, V. G., \& Yadav, G. (2020b). Towards understanding key enablers to green humanitarian supply chain management practices. Management of Environmental Quality: an International Journal, 31(5), 1111-1145.

Baharmand, H., Maghsoudi, A., \& Coppi, G. (2021). Exploring the application of blockchain to humanitarian supply chains: Insights from Humanitarian Supply Blockchain pilot project. International Journal of Operations and Production Management. https://doi.org/10.1108/IJOPM-12-2020-0884

Behl, A., Dutta, P., Sheorey, P., \& Singh, R. K. (2020). Examining the role of dialogic communication and trust in donation-based crowdfunding tasks using information quality perspective. The TQM Journal. https://doi.org/10.1108/TQM-06-2020-0139

de Camargo Fiorini, P., Chiappetta Jabbour, C. J., de Sousa, L., Jabbour, A. B., \& Ramsden, G. (2021). The human side of humanitarian supply chains: A research agenda and systematization framework. Annals of Operations Research. https://doi.org/10.1007/s10479-021-03970-Z

Dubey, R., Bryde, D. J., Foropon, C., Tiwari, M., Dwivedi, Y., \& Schiffling, S. (2021). An investigation of information alignment and collaboration as complements to supply chain agility in humanitarian supply chain. International Journal of Production Research, 59(5), 1586-1605.

Dubey, R., Gunasekaran, A., Bryde, D. J., Dwivedi, Y. K., \& Papadopoulos, T. (2020). Blockchain technology for enhancing swift-trust, collaboration and resilience within a humanitarian supply chain setting. International Journal of Production Research, 58(11), 3381-3398.

Dubey, R., Gunasekaran, A., Childe, S. J., Roubaud, D., Fosso Wamba, S., Giannakis, M., \& Foropon, C. (2019). Big data analytics and organizational culture as complements to swift trust and collaborative performance in the humanitarian supply chain. International Journal of Production Economics, 210, $120-136$.

Dubey, R., Luo, Z., Gunasekaran, A., Akter, S., Hazen, B. T., \& Douglas, M. A. (2018). Big data and predictive analytics in humanitarian supply chains: Enabling visibility and coordination in the presence of swift trust. International Journal of Logistics Management, 29(2), 485-512.

Ellison, P. B., \& Cook, R. A. (2020). Health economic analysis of pharmaceutical inventory levels. Journal of Humanitarian Logistics and Supply Chain Management, 10(4), 603-628.

Fosso Wamba, S. (2020). Humanitarian supply chain: A bibliometric analysis and future research directions. Annals of Operations Research. https://doi.org/10.1007/s10479-020-03594-9 
Franke, H., Foerstl, K., \& Heese, H. S. (2021). The interaction effect of goal misalignment and metaknowledge distribution on team decision making in operations and supply chain management. Decision Sciences, 52(2), 331-361.

Fuli, G., Foropon, C., \& Xin, M. (2020). Reducing carbon emissions in humanitarian supply chain: The role of decision making and coordination. Annals of Operations Research. https://doi.org/10.1007/s10479020-03671-Z

Gupta, S., Altay, N., \& Luo, Z. (2019). Big data in humanitarian supply chain management: A review and further research directions. Annals of Operations Research, 283(1-2), 1153-1173.

Hamedan, F., Orooji, A., Sanadgol, H., \& Sheikhtaheri, A. (2020). Clinical decision support system to predict chronic kidney disease: A fuzzy expert system approach. International Journal of Medical Informatics. https://doi.org/10.1016/j.ijmedinf.2020.104134

Ho, G. T. S., Tang, Y. M., Tsang, K. Y., Tang, V., \& Chau, K. Y. (2021). A blockchain-based system to enhance aircraft parts traceability and trackability for inventory management. Expert Systems with Applications. https://doi.org/10.1016/j.eswa.2021.115101

Jabbour, C. J. C., Jabbour, A., \& Sarkis, J. (2019). Unlocking effective multi-tier supply chain management for sustainability through quantitative modeling: Lessons learned and discoveries to be made. International Journal of Production Economics, 217, 11-30.

Jeble, S., Kumari, S., Venkatesh, V. G., \& Singh, M. (2019). Influence of big data and predictive analytics and social capital on performance of humanitarian supply chain: Developing framework and future research directions. Benchmarking, 27(2), 606-633.

John, L., Gurumurthy, A., Mateen, A., \& Narayanamurthy, G. (2020). Improving the coordination in the humanitarian supply chain: Exploring the role of options contract. Annals of Operations Research. https://doi.org/10.1007/s10479-020-03778-3

Kabra, G., Ramesh, A., Akhtar, P., \& Dash, M. K. (2017). Understanding behavioural intention to use information technology: Insights from humanitarian practitioners. Telematics and Informatics, 34(7), 1250-1261.

Karadağ, İ, Keskin, M. E., \& Yiğit, V. (2021). Re-design of a blood supply chain organizations with mobile units. Soft Computing, 25(8), 6311-6327.

Koliousis, I., He, Q., Wu, Q., \& Sarpong, D. (2020). Using an integrated humanitarian supply chain EPR system to improve refugee flow management: A conceptual framework and validation. Production Planning and Control. https://doi.org/10.1080/09537287.2020.1834134

Kumar, P., \& Singh, R. K. (2021). Application of Industry 4.0 technologies for effective coordination in humanitarian supply chains: A strategic approach. Annals of Operations Research. https://doi.org/10. 1007/s10479-020-03898-w

Makkar, S., \& Singh, A. K. (2021). Development of a spirituality measurement scale. Current Psychology, 40(3), 1490-1497.

Marić, J., Galera-Zarco, C., \& Opazo-Basáez, M. (2021). The emergent role of digital technologies in the context of humanitarian supply chains: A systematic literature review. Annals of Operations Research. https://doi.org/10.1007/s10479-021-04079-z

Modgil, S., Singh, R. K., \& Foropon, C. (2020). Quality management in humanitarian operations and disaster relief management: A review and future research directions. Annals of Operations Research. https://doi. org/10.1007/s10479-020-03695-5

Mushanyuri, B. E., \& Ngcamu, B. S. (2020). The effectiveness of humanitarian supply chain management in Zimbabwe. Journal of Transport and Supply Chain Management, 14, 1-11.

Nagendra, N. P., Narayanamurthy, G., \& Moser, R. (2020). Management of humanitarian relief operations using satellite big data analytics: The case of Kerala floods. Annals of Operations Research. https://doi. org/10.1007/s10479-020-03593-w

Negi, S., \& Negi, G. (2021). Framework to manage humanitarian logistics in disaster relief supply chain management in India. International Journal of Emergency Services, 10(1), 40-76.

Nunes, R. M. S., \& Pereira, S. C. F. (2021). Intellectual structure and trends in the humanitarian operations field. Annals of Operations Research. https://doi.org/10.1007/s10479-021-04022-2

Paciarotti, C., Piotrowicz, W. D., \& Fenton, G. (2021). Humanitarian logistics and supply chain standards. Literature review and view from practice. Journal of Humanitarian Logistics and Supply Chain Management, 11(3), 550-573.

Patil, A., Shardeo, V., Dwivedi, A., \& Madaan, J. (2021). An integrated approach to model the blockchain implementation barriers in humanitarian supply chain. Journal of Global Operations and Strategic Sourcing, 14(1), 81-103.

Patil, A., Shardeo, V., \& Madaan, J. (2020). Modelling performance measurement barriers of humanitarian supply chain. International Journal of Productivity and Performance Management. https://doi.org/10. 1108/IJPPM-01-2020-0031 
Polater, A. (2021). Dynamic capabilities in humanitarian supply chain management: A systematic literature review. Journal of Humanitarian Logistics and Supply Chain Management, 11(1), 46-80.

Prasad, S., Zakaria, R., \& Altay, N. (2018). Big data in humanitarian supply chain networks: A resource dependence perspective. Annals of Operations Research, 270(1-2), 383-413.

Prasanna, S. R., \& Haavisto, I. (2018). Collaboration in humanitarian supply chains: An organisational culture framework. International Journal of Production Research, 56(17), 5611-5625.

Rodríguez-Espíndola, O., Chowdhury, S., Beltagui, A., \& Albores, P. (2020). The potential of emergent disruptive technologies for humanitarian supply chains: The integration of blockchain, Artificial Intelligence and 3D printing. International Journal of Production Research, 58(15), 4610-4630.

Sahebi, I. G., Masoomi, B., \& Ghorbani, S. (2020). Expert oriented approach for analyzing the blockchain adoption barriers in humanitarian supply chain. Technology in Society. https://doi.org/10.1016/j.techsoc. 2020.101427

Schniederjans, D. G., Ozpolat, K., \& Chen, Y. (2016). Humanitarian supply chain use of cloud computing. Supply Chain Management, 21(5), 569-588.

Seifert, L., Kunz, N., \& Gold, S. (2018). Humanitarian supply chain management responding to refugees: A literature review. Journal of Humanitarian Logistics and Supply Chain Management, 8(3), 398-426.

Shafiq, M., \& Soratana, K. (2020). Lean readiness assessment model—a tool for Humanitarian Organizations' social and economic sustainability. Journal of Humanitarian Logistics and Supply Chain Management, 10(2), 77-99.

Sharma, P., \& Joshi, A. (2020). Challenges of using big data for humanitarian relief: Lessons from the literature. Journal of Humanitarian Logistics and Supply Chain Management, 10(4), 423-446.

Singh, R. K., Gupta, A., \& Gunasekaran, A. (2018). Analysing the interaction of factors for resilient humanitarian supply chain. International Journal of Production Research, 56(21), 6809-6827.

Sinha, A., Kumar, P., Rana, N. P., Islam, R., \& Dwivedi, Y. K. (2019). Impact of internet of things (IoT) in disaster management: A task-technology fit perspective. Annals of Operations Research, 283(1-2), 759-794.

Thompson, J. D. (1967). Organizations in action. McGraw-Hill Book Co.

Tushman, M. L., \& Nadler, D. A. (1978). Information processing as an integrating concept in organizational design. Academy of Management Review, 3(3), 613-624.

$\mathrm{Xu}$, W., Xiong, S., Proverbs, D., \& Zhong, Z. (2021). Evaluation of humanitarian supply chain resilience in flood disaster. Water (switzerland). https://doi.org/10.3390/w13162158

Xu, W. J., He, L. J., \& Zhu, G. Y. (2019). Many-objective flow shop scheduling optimisation with genetic algorithm based on fuzzy sets. International Journal of Production Research. https://doi.org/10.1080/ 00207543.2019 .1705418

Yang, H., Yang, L., \& Yang, S. H. (2011). Hybrid Zigbee RFID sensor network for humanitarian logistics centre management. Journal of Network and Computer Applications, 34(3), 938-948.

Yap, J. B. H., Leong, W. J., \& Skitmore, M. (2020). Capitalising teamwork for enhancing project delivery and management in construction: Empirical study in Malaysia. Engineering, Construction and Architectural Management, 27(7), 1479-1503.

Yu, Y., Huo, B., \& Zhang, Z. (2021). Impact of information technology on supply chain integration and company performance: Evidence from cross-border e-commerce companies in China. Journal of Enterprise Information Management, 34(1), 460-489.

Zhang, M., Huang, Q., Zhao, X., \& Ma, L. (2021). The impact of information integration on purchase order finance and new product launch: A case study. International Journal of Operations and Production Management, 41(4), 359-382.

Publisher's Note Springer Nature remains neutral with regard to jurisdictional claims in published maps and institutional affiliations. 